\title{
선진 공여기관의 분쟁 · 취약국 지원전략 및 성과관리
}

목 차

I. 서론

II. 선진 공여기관의 분쟁 - 취약국 지원전략: DFID를 중심으로

1. $\mathrm{DFID}$ 의 분쟁 · 취약국 지원 방향 및 개괄

2. 2015 新영국원조전략 내 분쟁 - 취약국 관련 주요 내용

3. DFID 신규 취약국가 및 지역 리스트 소개 및 분석

III. 선진 공여기관의 분쟁 - 취약국 측정 및 성과관리: DFID와 USAID 중심으로

1. DFID 분쟁 · 취약국 성과 프레임워크 및 지표풀

2. USAID 취약성 프레임워크 및 지표풀

IV. 한국 및 KOICA 분쟁.취약국 지원을 위한 시사점

1. 원조 규모 확대(scale-up) 및 범부처 간 참여의 필요성

2. 분쟁 및 취약국 지원전략 내 성과관리 프레임워크 구축 필요

\section{참고문헌}

〈Annex 1〉 DFID의 취약국 대상 지원 규모 및 순위변화 추이(2014-2015)

〈Annex 2〉 DFID의 취약국 대상 프로젝트 예산 규모 및 순위(FY16/17-FY17/18)

〈Annex 3〉 DFID 파키스탄 지원사례: AAWAZ 사업 


\section{요 약}

지난 오랜 기간 동안의 빈곤 해소를 위한 국제사회의 꾸준한 노력으로 인해 현재 전세계 빈곤수준은 많이 감소하였으나, 취약국(fragile states)에 대한 빈곤 집중현상은 도리어 갈수록 심화되고 있다. 이러한 상황에서 현재 국제사회에서는 지속가능개발목표 (Sustainable Development Goals, SDGs)의 효과적인 달성을 위해 분쟁 및 취약국 지원을 위한 전략 및 효과적인 성과관리 방안 마련에 대한 관심이 높아지고 있다. 하지만 분쟁 및 취약국 지원 자체가 갖는 외교 - 안보적 민감성과 높은 사업 리스크 등으로 인해 분쟁 및 취약국에 대한 글로벌 원조 규모는 지속적으로 감소하고 있는 실정이다. 그러나 이러한 상황에서 영국 국제개발부(Department for International Development, 이하 DFID) 및 미국 국제개발처(United States Agency for International Development, 이하 USAID)와 같은 몇몇 선진공여기관의 경우 분쟁 및 취약국 지원 예산을 지속적으 로 확대하고 있으며 동 대상 국가에 대한 지원전략 및 성과관리 방안의 개선을 통한 사업 효과성 강화를 위해서도 노력하고 있다.

이에 본 고에서는 선진 공여기관의 분쟁 및 취약국 지원전략 및 성과관리 방안을 $\mathrm{DFID}$ 와 USAID 사례를 중심으로 살펴봄으로써 한국 및 $\mathrm{KOICA}$ 의 분쟁 및 취약국 지원을 위한 시사점을 도출한다. 먼저 선진공여기관의 분쟁 및 취약국 지원전략은 최근 새로운 원조전략 및 취약국 리스트를 발표한 영국 DFID 사례 분석을 통해 효과적인 취약국 지원을 위한 원조 규모 확대 및 범부처 간 참여를 통한 공통 기금 마련의 필요성 을 도출한다. 아울러 분쟁 및 취약국의 거버넌스 측정 및 성과관리를 위한 함의는 $\mathrm{DFID}$ 와 USAID가 구축하고 있는 프레임워크 및 지표풀을 각각 살펴봄으로써 앞으로 $\mathrm{KOICA}$ 의 효과적인 취약국 지원사업 운영을 위한 성과관리 프레임워크 구축을 위한 함의를 도출한다. 


\section{I. 서 론}

지난 밀레니엄개발목표(Millenium Development Goals, 이하 MDGs) 시절에서부터 꾸준

히 진행되어온 빈곤 해소를 위한 국제적 노력으로 인해 현재 전세계 빈곤 수준은 많이 감소하였 으나, 취약국(fragile states)에 대한 빈곤 집중현상은 갈수록 심화되고 있다. 이로 인해 지난 MDGs가 종료된 2015년까지 전세계 하루 1.25 달러 이하로 생계를 살아가는 사람들의 절반이 취약국에 집중되어 있음이 밝혀졌다. 취약국에서 살아가는 사람들은 다른 개발도상국민들에 비해 영양실조 비중이 2 배 이상이며, 자신의 아이들을 학교에 보내지 못하는 수준 또한 타 개도국 대비 3 배 이상의 수준을 보였다. 사실상 10 년 전만 해도 대부분의 취약국들의 경우 저소득 국가에 해당하였으나 오늘날에는 취약국의 절반 이상이 중소득 국가에 해당되어 있다 (ICAI, 2015). 이러한 상황에서 현재 국제사회 모두가 이행하고 있는 지속가능개발목표 (Sustainable Development Goals, 이하 SDGs)의 효과적인 달성을 위해서도 취약국에 대한 보다 높은 관심 및 특수한 사정을 고려한 맞춤식 접근 전략과 성과관리 방안에 대한 국제적 관심이 높아지고 있다.

하지만 국제개발 차원에서 분쟁 및 취약국에 대한 이러한 높은 관심에도 불구하고, 분쟁 및 취약국 자체가 갖는 높은 리스크 및 낮은 사업 효과성 등으로 인해 취약국에 대한 국제적 차원의 전체 공적개발원조(Official Development Assistance, 이하 ODA) 비중은 지속적으 로 하락하고 있는 실정이다. 경제협력개발기구(Organization for Economic Cooperation and Development, OECD) 취약국 리스트 기준, 2011년도에는 취약국에 대한 글로벌 ODA지 원 규모는 2010년 대비 2.4\% 하락하였으며, 이후 최근 5년간 취약국에 대한 원조 규모 재조정 및 감소에 대한 많은 양자원조기관들의 정치적, 경제적 압박이 존재해온 것이 사실이다. 특히 취약국에 대한 원조의 경우 그 자체가 외교안보적으로 민감한 이슈로서 국가 간 정책방향 및 취약국가 내 존재하는 많은 변수로 인해 그 변동성(volatility)이 매우 심한 경향이 존재한다는 점에서 취약국에 대한 지원원조는 쉽지 않은 것이다(ICAI, 2015).

하지만 이러한 상황에서 영국 국제개발부(Department for International Development, 이하 DFID) 및 미국 국제개발처(United States Agency for International Development, 이하 USAID)와 같은 몇몇 선진공여기관의 경우 분쟁 및 취약국 지원 예산을 지속적으로 확대 하고 있으며 동 대상 국가에 대한 지원 전략 및 성과관리 방안의 개선을 통한 사업 효과성 강화를 위해서도 노력하고 있다.

또한 이러한 국제적 상황에서 한국 또한 '개발 없이 평화 없고, 평화 없이 개발 없다'는 인식에 
따라 개발협력을 활용한 국제사회의 분쟁 예방 및 평화구축에 대한 기여를 확대해나가고자 노력하고 있다. 이를 위해 최근 수립 중인 '제 2 차 국제개발협력 기본계획’에도 개발과 평화 간의 연계에 대한 한국 정부의 명확한 방향성을 비전으로 설정하였다. 또한 정부 차원에서 2015년도 기준으로 전체 양자ODA 중 30\%를 분쟁 및 취약국을 대상으로 지원하였으며, 현재 '취약국 지원전략'을 수립하여 분쟁 및 취약국에 대한 보다 구체적인 지원 목표 및 방향을 마련 하였다. 또한 한국국제협력단(Korea International Cooperation Agency, 이하 KOICA) 차 원에서도 이러한 정부의 노력에 기여하기 위해 분쟁 및 취약국 예산을 2017년 기준 108 억 원으로 증액하는 동시에 2017년 상반기에 ‘취약국 지원을 위한 중기이행전략(2017-2019)'을 수립한 바 있다. 특히 $\mathrm{KOICA}$ 의 취약국 지원전략 내에는 기관 차원에서의 취약국 정의 및 지원원칙, 지원대상 국가 선정 리스트, 추진 전략 등이 종합적으로 제시되어 있다는 점에서 $\mathrm{KOICA}$ 의 체계적인 취약국 지원을 위한 주요한 활용 지침이 될 것으로 기대되나, 현재로서는 동 전략에 기반하여 취약국 지원사업을 진행할 경우 성과관리를 어떻게 할 것인가에 대한 부분 은 현재 수립 중에 있어 제외되어 있다. 분쟁 및 취약국에 대한 개발 차원의 접근방식은 기타 다른 일반 원조사업과는 그 접근 및 관리 방안이 보다 차별성 있게 진행될 필요가 있다는 점에서 $\mathrm{KOICA}$ 차원에서도 취약국 대상 사업의 성과관리 방안에 대한 마련은 중요하다고 할 수 있다.

이러한 점에 기반하여 본고에서는 선진공여기관의 분쟁 및 취약국 지원전략 및 성과관리 방안을 $\mathrm{DFID}$ 와 $\mathrm{USAID}$ 사례를 중심으로 살펴보고자 한다. 특히 $\mathrm{DFID}$ 의 경우에는 최근 2015 년 영국 원조전략을 새로이 발표하면서 범부처 간 취약국 지원 기금을 증액하고 $\mathrm{DFID}$ 의 취약 국 지원 예산 또한 증대시키는 등의 방식을 통해 취약국 지원 예산을 확대하고자 하며, $\mathrm{DFID}$ 는 이에 기반하여 취약국 지원대상 국가 리스트를 새로이 개편하였다. 이러한 점에서 DFID의 사례를 중심으로 먼저 분쟁 및 취약국 지원을 위한 $\mathrm{DFID}$ 의 현재 새로운 움직임 현상은 어떠한 지를 전략 차원에서 제 ㅍ장에서 살펴보고자 한다. 그리고 나서 제 피장에서는 $\mathrm{DFID}$ 와 USAID 가 그간 오랜 경험 및 연구를 통해 구축해오고 있는 취약성 분석 및 성과관리를 위한 각각의 프레임워크와 지표풀을 소개함으로써 KOICA의 취약국 중기이행전략(2017-2019) 상에 현재 수립 중인 성과 프레임워크 구축을 위한 함의를 살펴보고자 한다. 이후 마지막 제 IV장에서는 앞선 논의를 바탕으로 향후 한국 및 $\mathrm{KOICA}$ 의 분쟁 및 취약국 지원방안 개선을 위한 시사점을 도출하고자 한다. 


\section{II. 선진 공여기관의 분쟁 · 취약국 지원 전략: DFID를 중심으로}

영국 정부는 최근 2015년 새로운 원조 정책을 발표하면서 '분쟁 예방 및 안보, 거버넌스 강화라는 영국의 원조 기조를 다시 한번 확인하는 동시에 취약국 지원과 관련한 지원 예산을 확대하였다. 분쟁 및 취약국 지원과 관련한 주요 내용 변화를 살펴보면, 지난 2010년 영국 원조전략(UK aid: Changing lives, delivering results, 이하 2010 영국원조전략)에서는 분 쟁 및 취약국의 평화건설을 위한 4 가지 주요 목표를 제시하고, 동 국가들에 대한 DFID의 지원 예산을 2015년까지 30\% 비중으로 늘리도록 확인한 바 있다. 이러한 정책목표를 바탕으로 지난 2011년 DFID는 안정성 구축 전략(Building Stability Overseas Strategy, 이하 $\mathrm{BSOS}$ )을 수립하여 불안정성과 갈등을 예방하고 신속하게 대처하기 위한 각종 대응전략을 수립하고 '취약국 안정화 구축 틀(building stability framework)'을 마련하는 등 다양한 지원 노력을 전개해오고 있다. 이러한 상황에서 2015년 신규 수립된 영국 원조 전략(UK aid: tackling global challenges in the national interest, 이하 2015 新영국원조전략)에서는 취약국 지원과 관련하여 기존의 DFID 예산 지원 규모를 $30 \%$ 에서 2020 년까지 $50 \%$ 로 증액하 였으며, 취약국 지원을 위한 범부처 차원의 기금도 신규 설립 및 증액하는 등 분쟁 및 취약국 지원을 위한 예산 마련 방안을 확대하는데 초점을 맞추고 있다. 아울러 DFID 또한 이러한 신규전략에 기반하여 지난 2016년 2월 새로운 '취약국가 및 지역 리스트'를 수립 및 발표함으로 써 보다 넓은 범위에서 효과적으로 전세계 취약성을 해소함으로써 자국의 안보 또한 강화하는 등 자국의 이익(national interest)을 수호하기 위한 전략 이행의 움직임을 보이고 있다.

영국 정부는 지난 2010년 '2010 to 2015 government policy: conflict in fragile states' 정책문서에서 '2015년까지 DFID 전체 ODA 규모의 30\%를 취약국가에 할당' 및 지원함으로써 동 국가 내의 불안정을 야기하는 요소들(drivers of instability)을 제거하는데 기여하겠다고 공약 한 바 있다. 이에 따라 DFID 또한 2011년 이후로 감소추세를 보이는 취약국 대상 글로벌 원조 흐름에도 불구하고 지속적으로 취약국 대상 원조 규모를 확대해왔으며, 이로 인해 DFID는 당시 전체 28개 중점협력국 중 21 개 국가를 '취약국 및 분쟁취약국(fragile and conflict-affected states)'로 분류하고 이에 대한 지원 예산을 지속적으로 확대하여 왔다(ICAI, 2015).

이러한 영국의 취약국 지원 정책기조 및 지원 규모는 지난 2015년 11월 영국 정부가 새로이 수립한 새로운 영국 원조 전략에서 보다 발전되었으며, 이러한 새로운 원조전략에 기반하여 지원대상으로서의 ‘취약국가 및 지역' 또한 재편되었다. 이에 동 장에서는 $\mathrm{DFID}$ 의 분쟁 및 취약국 지원을 위한 기본 방향 및 내용에 대해 살펴보고, 2015년 새로이 수립된 영국의 신 
원조전략의 주요 내용과 신규 취약국 리스트(new list of fragile states and regions)를 함께 살펴봄으로써 $\mathrm{DFID}$ 의 취약국 지원 기조 및 방식의 주요 특징은 무엇인지를 함께 살펴본 다. 아울러 동 신규 원조전략 및 정부재정계획에 따라 수립된 DFID의 신규 '취약 국가 및 지역 리스트'의 수립이 적절한지에 대한 분석을 함께 진행한다.

\section{DFID의 분쟁·취약국 지원 방향 및 개괄}

$\mathrm{DFID}$ 는 분쟁 및 취약국가 지원을 위한 다양한 중점 전략을 수립하고 있다. 먼저 $\mathrm{DFID}$ 의 '2010 영국원조전략'에서는 아래 <그림 1 >과 같이 분쟁 및 취약국 지원을 위한 4 가지 목표를 상정하고 있다. 포용적인 정치합의를 도모할 수 있도록 지원하고 국가의 핵심역할을 수행할 수 있도록 지원하며 취약국 내 일반 국민의 기대에 부응하도록 하며, 이들 간의 상호 영향 관계를 고려할 때 동 목표 달성을 위한 공통 요소로서 분쟁 및 취약성의 원인과 영향을 해결하고 분쟁해결 메커니즘을 구축하도록 한다. 이를 통해 최종적으로 '국가'와 '사회' 간의 연관성을 강화하는 것을 목표로 한다.

\section{〈그림 1〉 DFID 평화로운 국가 및 사회 건설을 위한 4대 목표}

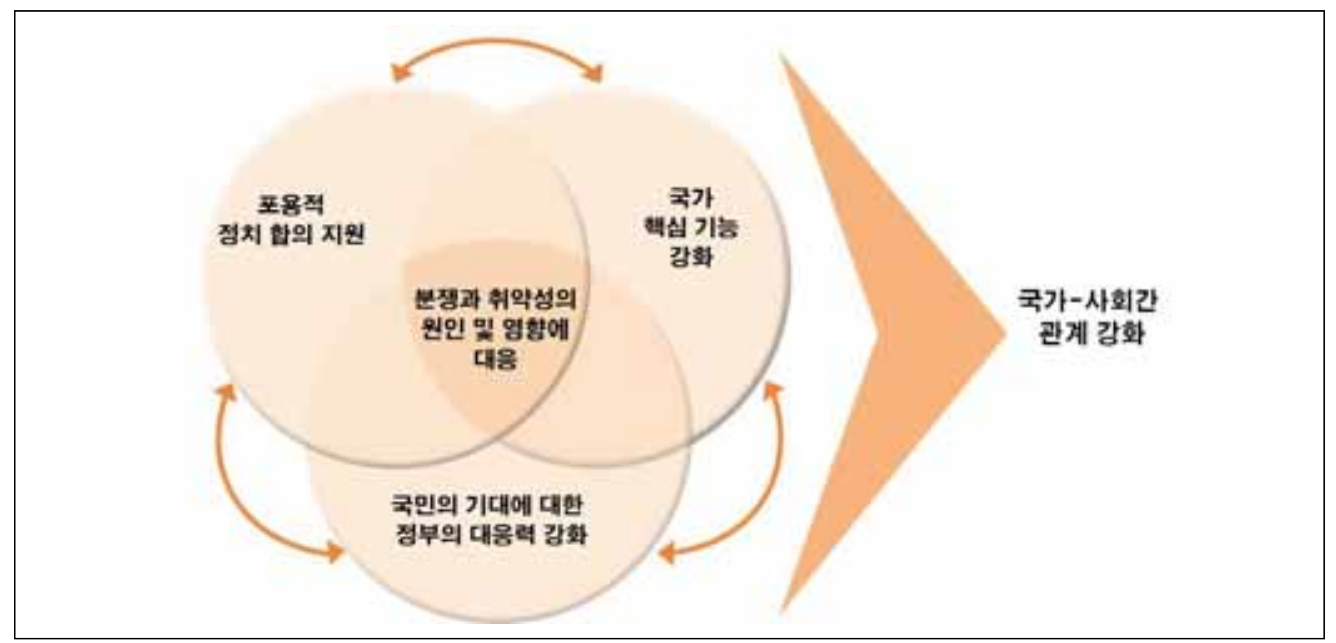

출처: DFID (2010a)

아울러 동 원조전략에서는 분쟁 및 취약국 지원을 위해 $\triangle$ 분쟁대응(counter conflict), $\triangle$ 대 상국 국민들에게 권한 부여(give people a voice), $\triangle$ 공정하고 자유로운 선거 개최 지원 (support freer and fairer elections), $\triangle$ 정부의 효과적인 세수 창출 기능 지원(help governments work better), $\triangle$ 안보 및 정의 구축 지원(deliver security and justice)를 
중점적으로 지원할 것을 밝히고 있다.

이러한 기본 목표를 바탕으로 한 $\mathrm{DFID}$ 의 '평화로운 국가 및 사회 구축 전략(building peace states and societies) practice paper(2010)'에서는 동 목표 달성을 위해서 특히 취약국 상황 에서의 실무적 함의점으로 $\triangle$ 분쟁 및 취약국에서의 정치(politics)는 지원사업을 하는데 있어 가장 중요한 핵심요소라는 인식, $\triangle$ 외부 파트너들과의 합의 구축, $\triangle$ 통합된 프레임워크 (integrated framework)를 사용하여 취약국이 처한 상황(context)분석, $\triangle$ 각국별 상이한 우선순위 및 선택사항들에 대한 고려 등을 제시하고 있다.

또한 DFID와 외무성(Foreign and Commonwealth Office, FCO)와 국방부(Ministry of Defence, MOD)가 2011년 공동 수립한 BSOS에서는 특히 분쟁국가에 대한 전략에 대해 다루고 있는데, 분쟁국가의 대다수가 취약국의 상황에 놓여 있음을 소개하고 있다. 또한 동 $\mathrm{BSOS}$ 문서를 바탕으로 영국 정부는 각 부처 간의 통합된 접근방식을 활용함으로써 분쟁 및 취약국 지원 시 외교·개발·국방 차원에서의 종합적인 요소를 고려함으로써 보다 효과적으로 분쟁 및 취약국 내 안정성을 구축할 수 있는 기반을 마련하고자 하였다. 분쟁 및 취약성 발발의 근원적 예방(upstream prevention)을 위해 $\mathrm{DFID}$ 는 취약성의 근본 원인을 해결해야 한다는 필요성에 공감하고 이에 중점을 둔 지원전략을 수립하였다. 또한 $\mathrm{DFID}$ 는 다양한 분쟁 및 취약 국 사례를 통해 분쟁 및 취약국의 초기 상황이 어떠한지에 대한 심도 있는 분석에 장시간 투자함으로써 새로운 분쟁 조기 경보 시스템(conflict early warning system)을 마련하는데 힘쓰고 있다.

동 $\mathrm{BSOS}$ 전략을 구성하는 주요 3대 요소는 다음과 같다.

\section{〈박스 1〉BSOS 전략 3대 주요 요소}

$\triangle$ 조기경보(early warning): 분쟁 유발 잠재요소 파악 및 불안정성 예측에 대한 DFID의 역량 강화

$\triangle$ 신속한 위기 예방 및 대응(rapid crisis prevention and response): 위기 예방 및 위기 악화를 예방하기 위한 신속하고 시의적절한 효과적인 조치 실시

$\triangle$ 근원적 예방을 위한 투자 강화(investing in upstreaming prevention): 긴장 및 충격을 관리하는 역량이 있는 취약국 내에 영향력 있고 합법적인 제도(institutions) 구축 및 강건한 사회(robust societies) 수립 지원

출처: DFID, MOD, FCO (2011)1)

DFID Practice Paper(2010)와 BSOS 문서(2011) 모두에서는 빈곤문제를 정치적 상황과 도 연계하여 보다 넓은 차원에서 인식하고, 이로 인해 야기되는 취약성의 가장 핵심적인 요인이

1) DFID, FCO, MOD. 2011. "Building Stability Overseas Strategy." London: UK Government 
무엇인지, 그리고 이를 해결하는데 있어 가장 주요한 도전과제는 무엇인지 등에 대한 고민이 필요함을 강조하고 있다. 또한 두 문서 모두 ‘획일적으로 사용되는(one size fits all)' 모델 방식보다는 분쟁 및 취약국이 처한 특수한 상황을 고려하여 동 국가에 대한 그간 접근 경험을 바탕으로 개입을 위한 개념적 기반 (conceptual foundations)또한 강화할 필요가 있다고 강조 한다. 하지만 $\mathrm{DFID}$ 뿐만 아니라 다양한 원조기관에서 이러한 인식에는 모두 공감하지만 이와 함께 공통적으로 직면하고 있는 문제 또한, 어떻게 이러한 개념적 사항을 실제 사업으로 옮길 수 있을까 하는 것이다.

지난 2011년 영국 정부는 약 40여 개의 국가 및 국제기구들과 함께 부산 고위급포럼(Busan High Level Forum)에서 '취약국 개입을 위한 뉴딜(New Deal for Engagement in Fragile States, 이하 뉴딜'’을 채택하였다. 뉴딜은 많은 취약국 내에서 우선 시범 시행되었는데, 다음 세 가지의 주요 요소를 포함하고 있다.

\section{〈박스 2〉 뉴딜(New Deal) 내 주요 3가지 요소2)}

1. 5가지 평화구축 및 국가건설 목표(Peacebuilding and Statebuilding Goals, PSGs)

(1) 정당한 정치(legitimate politics): 포용적인 정치합의 및 분쟁해결 방식 강화,

(2) 안보(security): 국민 안보 수립 및 강화,

(3) 정의(justice): 불공정 해소 및 국민의 사법 접근권 강화,

(4) 경제적 토대(economic foundations): 일자리 창출 및 생활환경 개선,

(5) 조세수입 및 서비스(revenues and services): 조세수입 관리 및 책임 있고 공정한 사회서비스 전달

2. 뉴딜에서의 취약국 개입 방식(FOCUS)

(1) 취약성 평가(fragility assessment)

(2) 하나의 비전 및 하나의 계획(one vision, one plan)

(3) 이행협약(compact)

(4) 모니터링에 PSGs 활용 (use PSGs to monitoring)

(5) 정치적 대화 및 리더십 지원 (support political debates and leadership)

3. 뉴딜에서의 취약국 개입 원칙(TRUST)
(1) 원조 투명성(transparency)
(2) 위험공유(risk sharing)
(3) 취약국의 시스템 사용 및 강화(use and strengthen country systems)
(4) 역량 강화(strengthen capacities)
(5) 시의적절하고 예측가능한 원조(timely and predictable aid)

출처: IDPS (2011)

2) 뉴딜의 목표(PSGs) 및 취약국 개입 방식·원칙(FOCUS \& TRUST)에 대한 상세사항은 '권혁주. 2015. 『분쟁 및 취약국 지원 현황 분석: 뉴딜이행 현황을 중심으로』. 성남: 한국국제협력단을 참조하기 바란다. 
2011 뉴딜 정책은 취약국뿐만 아니라 국제적 원조 파트너 모두가 '다르게 접근하자(do things differently)'는 기조를 가지고 접근할 것을 주문하고 있다. 이를 위해 평화구축 및 국가수립목표(PSGs)를 수립하고 이를 이행하기 위한 개입 방식(FOCUS)과 개입 원칙 (TRUST)을 별도로 수립하고 있다. 가령, 개입 시에는 위험관리(risk management)를 위해 서는 취약국의 사정에 보다 적합한 형태로 맞춤식 접근방식으로 이루어져야 한다는 것이다. 아울러 뉴딜에서는 취약국 접근 시 국별 시스템(country system)에 대한 투자를 늘리고 시의 적절하고 예측가능한 원조를 실시하며, 이를 위한 핵심적인 대상국 정부의 역량을 강화하는 것을 원칙으로 해야 한다고 강조하고 있는 것이다. 이에 영국 또한 취약국 지원 시 뉴딜 정책의 기본 목표 및 개입방식과 원칙을 이행하고자 하고 있다.

2010년 당시 영국 원조 정책에서 공약된 ' $\mathrm{DFID}$ 전체 원조 규모의 $30 \%$ 를 취약국에 할당한다' 는 기조는 사실상 $\mathrm{DFID}$ 로 하여금 다양한 새로운 리스크를 겪을 수밖에 없도록 했으며, 그중에 서도 대표적인 것이 수탁자리스크(fiduciary risk)이다. 이로 인해 사실상 취약국 대상 예산 증대(scale-up)은 쉽지 않은 것이 현실이다. 국별 수준에서 보면, 예산증대를 하고자 할 경우 $\mathrm{DFID}$ 는 다음과 같은 다양한 도전과제들에 직면할 수 있다.

\section{〈박스 3〉 취약국 지원 예산 증대(scale-up)시 예측가능한 리스크}

엉부 기관의 약화(weakness of government agencies)

○ 현지 파트너의 역량 부족(lack of capability in local partners)

○ 취약한 현지 시민 사회 (weakness of local civil society)

○ 현지 파트너의 흡수능력 제한 및 이로 인한 예산 증대 지연(limited absorptive capacity of local partner, resulting in slow scale-up)

O 제3자 의존력 강화- UN기구, INGOs, 다국적 조달 기관의 역량 종합 (reliance on third parties, e.g. UN agencies, international non-governmental organisations (INGOs) and mixed capabilities of multinational delivery agencies)

O 신뢰할만한 운송체인 구축 역량 약화 (the ability to establish reliable logistical chains)

O 안보 문제로 인한 DFID 직원의 대상 국가 정부 관련 부분 접근성 제한 (lack of access to parts of the county (or even the country as a whole) for DFID staff because of security issues)

O DFID 직원의 대상 국가 장기간 파견의 어려움 (difficulty in getting DFID staff to deploy to the country for long periods)

O 취약국의 상기와 같은 상황에서 제대로 작동하는 방식에 대한 실질적인 증거 부족(poor evidence of what works in such environments)

출처: ICAI (2015)

상기 <박스 $3>$ 와 같은 많은 리스크로 인해 분쟁 및 취약국 지원시 DFID가 해결해야 할 과제들 또한 증대된다고 할 수 있다. 또한 상기와 같은 문제들을 고려하고 대상 국가 내에서 효과적인 사업을 기획 및 운영할 수 있을 만큼의 내부적인 역량을 가지고 있는지에 대한 자체적 
인 점검도 필요하다. 아울러 뒤에서도 설명하겠지만, 지난 2015년 새로운 영국 원조전략에서 공약한 바와 같이 분쟁 및 취약국에 대한 $\mathrm{DFID}$ 의 지원 예산 비중 및 범부처 차원의 분쟁 및 취약국 지원 기금 또한 확대해가는 상황에서 국제개발 차원에서 영국의 분쟁 및 취약국 지원 노력의 중심에 서 있는 $\mathrm{DFID}$ 가 실제 충분한 역량을 가지고 있는지에 대한 지속적인 점검 및 개선방안 고찰은 필요하다고 할 수 있다.

이로 인해 $\mathrm{DFID}$ 는 이미 분쟁 및 취약국 내에서의 프로젝트 기획을 위한 메커니즘 및 원조 조달 방식 등이 강화되어야 한다는 필요성을 느끼고 이에 대한 다양한 노력을 진행해오고 있다. 지난 2010년 발간된 '취약국 국별 프로그램 평가 종합(synthesis of country programme evaluations in fragile states)' 보고서에서는 DFID가 취약국 대상 원조 조달을 위한 보다 효과적인 방법을 찾기 위해 노력하고 있으며, 리스크를 줄이기 위해서는 모범적인 성과를 보이 는 수혜국(good performers)보다는 취약국에게 보다 다양한 원조 수단들이 사용되어야한다는 기본 방향 하에 다양한 노력을 해오고 있다고 평가하고 있다.

\section{2015 新영국원조전략 내 분쟁·취약국 관련 주요 내용}

지난 2015년 11월 재무부(UK treasury)와 DFID 주도로 영국 정부는 'UK aid: tackling global challenges in the national interest'란 제목의 새로운 영국 원조전략을 발표하였다. 동 원조전략은 기존의 $\mathrm{DFID}$ 에 과도하게 편중되어 운영되어온 영국 원조를 '범부처(crossministries)' 차원에서 보다 균형을 유지하며 원조를 운영할 수 있도록 하는 최초의 원조전략이 라는 점에서 의의를 가진다. 동 원조전략에서는 대규모 이주, 질병, 불안정, 글로벌 기후변화 등 다양한 주요 글로벌 도전과제들에 대한 영국 원조의 해결 의지와 함께 분쟁 및 취약국에 대한 지원 목표 및 방향 또한 보다 분명하게 밝히고 있으며, 특히 분쟁 및 안보 분야에 대한 비중이 보다 강화되었음을 알 수 있다. 이러한 원조 정책 전략의 기조는 DFID의 앞으로의 분쟁 및 취약국 지원 방향 수립 및 이행에도 주요한 기반이 된다는 점에서 주목할 필요가 있다. 아래 <표 1>는 2015 新영국원조전략에서 밝히고 있는 주요 4대 목표(objectives)와 동 목표 달성을 위한 8가지의 주요 활동(activities)사항을 정리한 표이다.

동 전략에서 사실상 가장 중요한 특징 중의 하나는 영국 원조전략의 이행이 $\mathrm{DFID}$ 에 편중된 형태가 아니라 범부처(cross-ministries) 차원의 새로운 접근방식을 포함하고 있으며, 총국민 소득(Gross National Income, GNI)의 $0.7 \%$ 를 ODA에 사용하겠다는 정부 의지가 보이고 있다(활동 7 )는 점이다. 이는 분쟁 및 취약성 해소, 평화구축, 글로벌 빈곤퇴치 등은 국제사회에 서의 영국의 지위를 공고히 할 뿐만 아니라, 이를 통해 자국민들의 삶 또한 보호할 수 있다는 
자국의 국익 차원에서도(in the national interest) 강조되는 부분으로, 이로 인해 보다 투명하 고 책무성 있는 원조집행 또한 중요시 여겨지고 있다(활동 8). 이러한 ODA 비중 확대 및 투명한 집행은 영국 보수당(Conservative Party)이 2015년 총선 당시 내세웠던 국제개발 관련 공약내용(manifesto)에서 주요하게 제시되어 영국 정부가 전면 이행하게 된 부분으로, 이는 2017년 총선에서의 영국 보수당 공약에서도 그대로 이어지고 있다.

〈표 1〉 2015 新영국원조전략 주요 목표(objectives) 및 활동(activities)

\begin{tabular}{l} 
목표(objectives) \\
\hline 1. 글로벌 평화, 안보, 거버넌스 강화 \\
2. 위기로부터의 복원력 및 대응력 강화 \\
3. 글로벌 번영 도모 \\
4. 극빈곤 척결
\end{tabular}

활동(activities)

1. $\mathrm{DFID}$ 총예산의 $50 \%$ 를 취약국가 및 지역에 할당

2. 시리아 위기 및 관련 지역에 대한 원조 비용(aid spending) 증대

3. 전통적인 일반예산지원(general budget support) 일체 종료 및 target spending 증대 기반 마련

4. 자금 규모가 증대된 범부처 간 '분쟁, 안정성, 안보 기금(Conflict, Stability and Security Fund, CSSF)' 를 활용하여 '중앙안보위원회(Natioanl Security Council, NSC)의 국제업무를 지원함으로써 신규전 략상의 안보 목표 이행.

5. 신규 10 억 파운드를 약정하여 글로벌공공보건기금 (Global public health, 이하 Ross Fund)을 마련하 여 말라리아와 같은 긴급한 전염병을 해소하는데 기 여하고자 함. 동 Ross Fund는 에볼라, 소외열대질 환(neglected tropical disease) 등과 같은 유행성질 환 발발 가능성 및 약제 내성균 감염(Drug resistant infections) 등을 해소하는데 기여하고자 함.

6. '중앙안보위원회(NSC)'주도로 마련된 신규 범부처 간 번영 기금(Prosperity Fund)을 사용하여 글로벌 번영 도모 목표 달성을 위해 기여.

7. 영국 총국민소득(GNI)의 $0.7 \%$ 를 ODA에 할당함으로 써 빈곤감소, 글로벌 도전과제 해결뿐만 아니라 영 국의 국가 차원의 이해(national interest) 도모를 위 해 활용.

8. 원조에 사용된 모든 예산은 납세자들로부터 나온 소중한 자금임을 명심하고 불필요한 프로젝트는 일 체 중단(cancel)하겠음.

출처: UK Government (2015)

이러한 주요 특징과 함께 취약국 지원과 직접 관련한 부분을 보면 우선 영국의 취약국 지원 확대 기조에 따라 $\mathrm{DFID}$ 는 전체 원조 규모의 $50 \%$ 를 취약국에 지원한다(활동 1 ). 이는 영국 정부의 2010 영국원조전략에서 명시한 '2015년까지 DFID ODA 규모 전체의 30\%를 취약국에 할당한다.'는 부분의 비율이 2020년까지 50\% 할당으로 높아졌다는 점에서 중요한 변화라 할 
수 있다.

또한 동 신규전략에서는 범부처 차원의 CSSF 기금3)을 오는 2019/20년까지 연간 13 억 파운드 수준으로 조성하고(활동 3), Prosperity Fund는 2016년부터 2020년까지 5개년간 총 13 억 파운드를 조성할 것(활동 6)을 확인하였다(UK Government, 2016). 특히 이 중에서 분쟁 - 취약국 지원을 위한 주요 범부처 기금인 $\mathrm{CSSF}$ 의 예산을 보면 아래 <표 2>에서와 같이, 동 전략이 발표된 첫해인 2015/2016년에는 약 10억 3,300만 파운드가 책정되었고 2016/ 17 년도에는 11 억 2,700 만 파운드가 책정되었다. 이는 $\mathrm{CSSF}$ 의 전 형태인 분쟁기금(conflict pool)이 집행 마지막 회계연도인 2014/15년에 6억 8,300만 파운드가 책정된 것에 비하면 지원 금액이 상당 부분 증대되었다고 할 수 있다.

\section{〈표 2〉2015/16 및 2016/17년도 CSSF 기금 예산 구성}

(단위: 백만 파운드)

\begin{tabular}{c|c|c}
\hline 항목 & $2015 / 16$ & $2016 / 17$ \\
\hline 평화유지 및 다자지원 & 462 & 385.7 \\
\hline 지역/국별 전략 & 482.8 & 577.8 \\
\hline 안보 및 방위 & 75 & 150 \\
\hline $\begin{array}{c}\text { 안정화 본부(stabilisation unit) 및 국립국제행정학교(national } \\
\text { school of government international) 등 }\end{array}$ & 13.2 & 13.5 \\
\hline 총합 & 1,033 & 1,127 \\
\hline
\end{tabular}

출처: UK House of Lords (2017)

또한 영국 내 분쟁 예방 및 안보 강화 등을 통한 취약국 지원 기조가 강화되어감에 따라 상기의 범부처 간 CSSF 및 prosperity Funds 증대와 함께 영국은 갈수록 악화되는 시리아

3) 분쟁, 안정성, 안보 기금(Conflict, Stability and Security Fund, CSSF)기금이란 영국의 전략적 중요성을 갖는 국가 내에서 존재하는 분쟁 및 불안정성의 원인 및 영향력을 척결하는데 사용하는 정부 자금을 말하는 것으로 이전의 영국 Conflict Pool을 변환시킨 것임. Conflict Pool은 2001년에 형성되어 크게 '아프리카분쟁예방기금(Africa Conflict Prevention Pool)과 국제분쟁예방기금(global conflict prevention pool)로 구성되었다가 2009년 '분쟁기 금(conflict pool)'으로 통합되어 2014/15년까지 운영되다 2015/16부터는 CSSF로 전환됨. CSSF와 마찬가지로 분쟁풀 또한 범부처 간 기금으로 분쟁에 취약한 전세계 사람들의 피해를 줄이기 위한 다양한 활동에 사용됨. 하지만 $\mathrm{CSSF}$ 와 다른 점은, 분쟁풀 기금의 경우 크게 '영국외무성(Foreign and Commonwealth Office, $\mathrm{FCO}$ ), '국제개 발부(DFID)', '국방부(Ministry of Defence, MOD),' 등 총 3개 부처에 의해 운영되었으나, 현재는 FCO, DFID, MOD 뿐만 아니라 이민국(home office), '국가범죄수사국(National Crime Agency, NCA),' '검찰(Crown Prosecution Service, CPS)', '보안정보기관(security and intelligence agencies)' 등 많은 정부 부처 및 기관들이 참여하고 있음. (출처: UK House of Lord. HLPaper105 "Conflict, Stability and Security Fund: Second Report of Session 2016-2017, available at https://www.publications.parliament.uk/pa/jt201617/jtselect/jtnatsec/ 208/208.pdf) (접속일: 2017.06.02.) 
위기에 대한 대응을 위한 예산을 증대 (활동 2)하고 이 외에도 새롭게 출연하는 위기에 대응하기 위해 5 억 파운드 규모의 위기대응기금(crisis reserve fund) 또한 신규 설립하여 운영하는 등 다각적인 노력을 보이고 있다.

제I장

spending review) 문서에 의거하여 작년 2016년 2월 새롭게 '취약국가 및 지역 리스트(fragile states and regions list)'를 선정 및 발표하였다. 각 공여기관들마다 갖고 있는 취약국 또는 취약성에 대한 정의 및 범위는 각기 상이하기 때문에 각 기관이 정의하고 있는 취약성 개념 및 전략적 파트너십의 중요도에 따라 취약국가 대상이 정해지게 된다. 특히 취약성(fragility)이 란 실제로 단순히 일국 차원으로 국한되어 해결될 수 있는 문제가 아니며, 지역 차원의 분쟁 또는 갈등이 발발 및 확산, 자연재해에 대한 지역 차원의 공동 대응 등 지역 차원으로 그 범주를 확대하여 고려해야 할 필요가 있다. 이러한 점에서 $\mathrm{DFID}$ 의 경우 취약국(fragile state)을 폭력 을 발생시키는 사회적·외부적 압력에 취약하고, 분쟁 및 갈등이 발생한 상황에서 또 다른 폭력적인 방법 외에는 사실상 통제할 수 있는 역량이 부족한 국가로 정의하고, 그 범위를 국가뿐 만 아니라 지역 차원으로 확대하고 있다. 따라서 2016년 2월 신규 발표된 취약국 리스트 또한 폭력 및 분쟁, 갈등 상황에 노출된 정도에 따라 63 개의 국가 뿐만 아니라 3 개의 지역을 포함하여 총 67개 지원대상 리스트를 확정하였다.

하단 <표 3>는 DFID의 신규 '취약국가 및 지역 리스트(fragile states and regions list)'이 다. 표에서와 같이 $\mathrm{DFID}$ 는 분쟁 예방 및 안보 강화 기조에 따라 폭력 및 분쟁, 갈등 상황에 직접 노출된 국가들의 노출 정도에 따라 '높은 취약성(high fragility), '중간 취약성(moderate fragility),' '낮은 취약성(low fragility)'으로 카테고리를 분류하였다. 또한 취약성의 특성상 주변국 및 지역 차원으로 확산될 가능성이 높고 이로 인해 지역 차원의 공동 대응이 보다 강조되는 것이 취약국 이슈라는 점에서, 이러한 직접적인 분쟁취약국가는 아니지만 높은 취약성 을 보이는 국가들에 대한 지리적 근접성으로 인해 취약성이 파급(spill-over)될 위험에 직면한 주변국들 또한 '높은 취약성 국가 인접국(neighbouring high fragility states)'으로 분류하고 있으며, 중점 취약 지역(regions) 또한 별도로 3개를 선정하여 카테고리에 포함시키고 있다. 특히 이러한 주변 인접 국가 및 지역 단위까지 취약국 리스트에 포함시킨 것은 $\mathrm{DFID}$ 의 ‘beyond fragile states’라는 전략적 기조를 반영한 결정이라 할 수 있다. 
〈표 3〉DFID 신규 취약국가 및 취약지역 리스트

\begin{tabular}{|c|c|c|c|c|}
\hline $\begin{array}{l}\text { 높은 취약성 } \\
\text { (high fragility) }\end{array}$ & $\begin{array}{l}\text { 중간 취약성 } \\
\text { (moderate } \\
\text { fragility) }\end{array}$ & $\begin{array}{l}\text { 낮은 취약성 } \\
\text { (low fragility) }\end{array}$ & $\begin{array}{c}\text { 높은 취약성 국가 } \\
\text { 인접국(neighbouring } \\
\text { 'high fragility' states) }\end{array}$ & $\begin{array}{l}\text { 취약 지역 } \\
\text { (regions) }\end{array}$ \\
\hline 아프가니스탄 & 앙골라 & 벨라루스 & 알제리 & 중동지역 \\
\hline 버마 & 아제르바이잔 & 캄보디아 & 아르메니아 & 사하라이북 지역 \\
\hline 부룬디 & 방글라데시 & 카메룬 & 요르단 & 사하라이남 지역 \\
\hline 중앙아프리카공화국 & 이집트 & 콜롬비아 & 라오스 & \\
\hline 차드 & 에티오피아 & 콩고 & 르완다 & \\
\hline 콩고민주공화국 & 기니 & 코트디부아르 & 탄자니아 & \\
\hline 이란 & 기니비사우 & 지부티 & 태국 & \\
\hline 이라크 & 아이티 & 온두라스 & 튀니지 & \\
\hline 에리트리아 & 케냐 & 라이베리아 & 터키 & \\
\hline 북한 & 키르기스스탄 & 마다가스카르 & 잠비아 & \\
\hline 리비아 & 레바논 & 모리타니 & & \\
\hline 파키스탄 & 말리 & 네팔 & & \\
\hline 소말리아 & 나이제리아 & 니제르 & & \\
\hline 남수단 & $\begin{array}{c}\text { 팔레스타인점령 } \\
\text { 지역(OPT) }\end{array}$ & 파라과이 & & \\
\hline 수단 & 타지키스탄 & 시에라리온 & & \\
\hline 시리아 & 투르크메니스탄 & 동티모르 & & \\
\hline \multirow[t]{3}{*}{ 예멘 } & 우즈베키스탄 & 우간다 & & \\
\hline & 베네수엘라 & 우크라이나 & & \\
\hline & 짐바브웨 & & & \\
\hline 17국 & 19국 & 18국 & 10국 & 3지역 \\
\hline
\end{tabular}

출처: IDC (2015)

상기 취약국가 및 지역 리스트 선정을 위해 DFID는 세계은행(world bank), 유엔(United Nations, UN)에서 발표하는 주요 취약국 관련 지표들과 함께 세계평화지수(global peace index) 등 각 공신력 있는 기관에서 발표하는 취약국 관련 데이트들을 활용하였다. 이러한 데이터들과 함께 $\mathrm{DFID}$ 자체의 다음과 같은 고려사항들을 종합하여 총 64 개의 국가와 3 개의 지역으로 구성된 리스트를 확정하게 되었다. 하지만 주요 지표 뿐만 아니라 아래의 DFID 추가 고려사항들의 데이터들 또한 시간이 지남에 따라 그 수치 또한 변화되어 갈 수 있기 때문에 취약국 리스트 또한 그에 맞추어 정기적으로 업데이트될 계획이다. 
〈박스 4〉DFID 신규 취약국가 및 지역 리스트 선정을 위한 기준

- 세계은행(World Bank) : Country Policy and Institutional Assessment(CPIA)

- 평화를 위한 기금(Fund for Peace): Failed States Index

- Uppsala Conflict Database

- DFID 기존 취약국 리스트 상의 국가(countries on DFID's Fragile States List)

- '높은 취약성(high fragility)'을 보이는 국가에 인접한 주변국 중 ODA지원이 가능한 국가 (단, 중국 및 인도 제외) (ODA-eligible countries neighbouring 'high fragility' states)

- 중동, 사하라 이북, 사하라 이남 지역 등 총 3 개 선정 지역에서 운영되는 지역차원의 프로그램 운영 현황 (regional programmes in three specifically designated fragile states)

출처: IDC (2015)4)

앞선 2015 新영국원조전략 내 취약국 지원과 관련하여 가장 주목할 부분은 '매년 DFID 전체 예산 중 $50 \%$ 를 취약국가 및 지역(fragile states and regions)에 배분한다'는 부분이다. 이는 2015년까지 DFID 전체 ODA규모의 30\%를 취약국에 배분하겠다는 2010년 공약과 비교 하였을 때 $\mathrm{DFID}$ 의 평화예방 및 안보 강화 기조에 따라 취약국 지원 예산이 증대되고, 이로 인해 보다 다각적이고 효과적인 취약국 지원사업을 운영할 수 있게 되었다는 점에서 유의미하다 고 할 수 있다. 그렇다면 ‘50\% 수준으로 취약국 지원 예산증대’ 목표가 설정된 이후 발표된 $\mathrm{DFID}$ 신규 '취약국가 및 지역 리스트'는 얼마나 적절하게 설정되었고 어떠한 의미를 갖는지에 대해 살펴볼 필요가 있다.

아래 <표 4>는 DFID의 신규 취약국 리스트에 포함된 63개 국가와 3개 지역 중 2014년과 2015년 실제 DFID 지원이 이루어진 국가/지역의 지원 규모 및 순위변화를 나타낸 표이다. 먼저 동 표에서의 2014년과 2015년에 이루어진 전체 ODA 지원금액과 취약국 대상 지원금액을 비교해보면, 2014년에는 52.3\%, 2015년도에는 전년보다 1.5\% 오른 53.9\%으로, 이는 2015년 당시 설정된 $50 \%$ 지원 목표를 이미 초과한 수치임을 알 수 있다.

아울러 하단 표의 주석 부분에 제시되어 있는 바와 같이 2개년도 연속 DFID로부터 일체 ODA 지원이 이루어지지 않은 국가가 26 개국에 해당하며 이는 전체 취약국가 및 지역 대비 절반에 육박하는 수치라는 점에서 대상 취약국에 대한 실제 예산 배분이 제대로 이루어질 수 있는지에 대한 우려가 제기된다. 가령 2014년의 경우 버마, 차드, 이슬람, 북한 등 총 4개의 '높은 취약성(high fragility)' 국가를 비롯해 총 26개국이 제외되어 있으며, 2015년에는 이러한 4 개의 국가와 함께 부룬디, 에리트리아 등 '높은 취약성' 국가 2개가 추가 제외되는 것을 포함하 여 전체 67 개 대상에서 41 개 취약국가 및 지역이 지원 예산 배분에서 제외되고 있다. 이러한 점을 보았을 때 과연 2개년간 DFID로부터 지원을 받지 못한 국가 또는 예산이 일절 삭감된 국가들의 경우 앞으로 실제 예산 할당이 이루어질 수 있을지, 그리고 이러한 취약국가 및 지역 선정 과정은 적절했는지 등에 대한 의문이 제기된다.

4) IDC Inquiry: Allocation of Resources (memorandum by DFID) (2015.11.) 
〈표 4〉 2014-2015년 DFID의 취약국 대상 ODA 지원 현황

\begin{tabular}{|c|c|c|c|c|c|c|c|c|c|}
\hline \multirow{2}{*}{ 번호 } & \multirow{2}{*}{ 국가명 } & \multirow{2}{*}{ 취약성 수준 } & \multicolumn{3}{|c|}{ 지원액 (단위: 백만 달러) } & \multicolumn{4}{|c|}{ 지원액 순위 } \\
\hline & & & 2014 & 2015 & 증감(15/14) & 2014 & 2015 & 증감(15/1 & \\
\hline 1 & 에티오피아 & 중간 취약성 & 525.3 & 510.8 & $14.5 \nabla$ & 1 & 2 & & $\nabla$ \\
\hline 2 & 파키스탄 & 높은 취약성 & 395.8 & 537.5 & $141.7 \Delta$ & 2 & 1 & & $\Delta$ \\
\hline 3 & 시에라리온 & 낮은 취약성 & 387.1 & 334.1 & $53.0 \nabla$ & 3 & 4 & & $\nabla$ \\
\hline 4 & 나이지리아 & 중간 취약성 & 372.8 & 387.8 & $15.0 \triangle$ & 4 & 3 & & $\triangle$ \\
\hline 5 & 방글라데시 & 중간 취약성 & 333.7 & 245.2 & $88.4 \nabla$ & 5 & 9 & 45 & \\
\hline 6 & 아프가니스탄 & 높은 취약성 & 293.7 & 305.0 & $11.4 \Delta$ & 6 & 8 & $2 \nabla$ & $\nabla$ \\
\hline 7 & DR콩고 & 높은 취약성 & 270.2 & 212.9 & $57.3 \nabla$ & 7 & 12 & 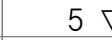 & $\nabla$ \\
\hline 8 & 남수단 & 높은 취약성 & 267.3 & 313.9 & $46.6 \triangle$ & 8 & 5 & 34 & \\
\hline 9 & 탄자니아 & ‘높은 취약성’ 국가 주변국 & 236.3 & 305.2 & $68.8 \triangle$ & 9 & 7 & 24 & $\triangle$ \\
\hline 10 & 중동지역 & 취약 지역 & 244.7 & 25.4 & $219.3 \nabla$ & 10 & 33 & $23 \nabla$ & $\nabla$ \\
\hline 11 & 케냐 & 중간 취약성 & 198.3 & 226.7 & $28.4 \triangle$ & 11 & 11 & 15 & $\nabla$ \\
\hline 12 & 우간다 & 낮은 취약성 & 184.5 & 176.4 & $8.1 \nabla$ & 12 & 13 & $2 \nabla$ & $\nabla$ \\
\hline 13 & 소말리아 & 높은 취약성 & 182.1 & 175.1 & $7.0 \nabla$ & 13 & 14 & $2 \nabla$ & $\nabla$ \\
\hline 14 & 네팔 & 낮은 취약성 & 180.8 & 124.4 & $56.4 \nabla$ & 14 & 20 & 75 & $\nabla$ \\
\hline 15 & 시리아 & 높은 취약성 & 165.9 & 311.2 & $145.3 \Delta$ & 15 & 6 & 84 & $\Delta$ \\
\hline 16 & 사하라이남지역 & 취약지역 & 178.4 & 152.5 & $25.8 \nabla$ & 16 & 16 & & - \\
\hline 17 & 짐바브웨 & 중간 취약성 & 156.9 & 133.2 & $23.7 \nabla$ & 17 & 18 & 35 & $\nabla$ \\
\hline 18 & 잠비아 & ‘높은 취약성’ 국가 주변국 & 133.3 & 77.8 & $55.4 \nabla$ & 18 & 25 & 95 & $\nabla$ \\
\hline 19 & 예멘 & 높은 취약성 & 128.0 & 119.0 & $9.0 \nabla$ & 19 & 22 & 50 & $\nabla$ \\
\hline 20 & 르완다 & 높은 취주변국 & 76.3 & 151.1 & $74.8 \triangle$ & 20 & 17 & 14 & $\Delta$ \\
\hline 21 & 이라크 & 높은 취약성 & 48.5 & 69.1 & $20.6 \triangle$ & 21 & 28 & 95 & $\nabla$ \\
\hline 22 & 레바논 & 중간 취약성 & 30.9 & 130.3 & $99.5 \triangle$ & 22 & 19 & 14 & $\triangle$ \\
\hline 23 & 중앙아프리카 & 높은 취약성 & 26.0 & 27.9 & $1.9 \Delta$ & 23 & 32 & $11 \nabla$ & $\nabla$ \\
\hline 24 & 타지키스탄 & 중간 취약성 & 19.5 & 17.5 & $2.0 \nabla$ & 24 & 34 & $12 \nabla$ & $\nabla$ \\
\hline 25 & 요르단 & ‘높은 취약성’ 국가 주변국 & 16.6 & 65.9 & $49.3 \triangle$ & 25 & 29 & 65 & $\nabla$ \\
\hline 26 & 카메룬 & 낮은 취약성 & 16.5 & 7.3 & $9.1 \nabla$ & 26 & 41 & $17 \nabla$ & $\nabla$ \\
\hline 27 & 부룬디 & 높은 취약성 & 9.9 & 0.0 & $9.9 \nabla$ & 27 & - & & - \\
\hline 28 & 라이베리아 & 낮은 취약성 & 9.2 & 15.8 & $6.5 \triangle$ & 28 & 35 & 95 & $\nabla$ \\
\hline 29 & 에리트리아 & 높은 취약성 & 9.2 & 0.0 & $9.2 \nabla$ & 29 & - & & - \\
\hline 30 & 아이티 & 중간 취약성 & 7.6 & 5.6 & $2.0 \nabla$ & 30 & 43 & $15 \nabla$ & $\nabla$ \\
\hline 31 & 키르기스스탄 & ‘높은 취약성’ 국가 주변국 & 6.8 & 2.5 & $4.2 \nabla$ & 31 & 46 & $17 \nabla$ & $\nabla$ \\
\hline 32 & 터키 & ‘높은 취약성’ 국가 주변국 & 6.4 & 2.0 & $4.4 \nabla$ & 32 & 51 & $21 \nabla$ & $\nabla$ \\
\hline 33 & 우크라이나 & 낮은 취약성 & 4.8 & 24.3 & $19.5 \nabla$ & 33 & 34 & 35 & $\nabla$ \\
\hline 34 & 리비아 & 낮은 취약성 & 4.4 & 3.1 & $1.3 \nabla$ & 34 & 45 & $13 \nabla$ & $\nabla$ \\
\hline 35 & 캄보디아 & 낮은 취약성 & 2.1 & 2.4 & $0.4 \Delta$ & 35 & 47 & $14 \nabla$ & \\
\hline 36 & 라오스 & ‘높은 취약성’ 국가 주변국 & 1.3 & 2.3 & $1.1 \triangle$ & 36 & 48 & $14 \nabla$ & \\
\hline 37 & 튀니지아 & ‘높은 취약성’ 국가 주변국 & 1.0 & 0.3 & $0.8 \nabla$ & 37 & 56 & $21 \nabla$ & \\
\hline 38 & 이집트 & 중간 취약성 & 0.9 & 1.1 & $0.2 \triangle$ & 38 & 54 & $18 \nabla$ & $\nabla$ \\
\hline 39 & 모리타니아 & 낮은 취약성 & 0.5 & 0.0 & $0.5 \nabla$ & 39 & - & & - \\
\hline 40 & 말리 & 중간 취약성 & 0.4 & 0.0 & $0.4 \nabla$ & 40 & 55 & 175 & \\
\hline 41 & 사하라북방지역 & 취약 지역 & 0.0 & 0.0 & - & 41 & - & & 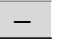 \\
\hline \multicolumn{3}{|c|}{ 취약국 지원 합계 $(\mathrm{A})$} & $5,133.5$ & 5202.8 & $69.3 \triangle$ & & & & \\
\hline \multicolumn{3}{|c|}{ 총 ODA 지원 합계 $(\mathrm{B})$} & $9,809.2$ & $9,662.3$ & $146.9 \nabla$ & & & & \\
\hline \multicolumn{3}{|c|}{ 전체 지원액 대비 취약국 지원 비중(A/B) } & $52.3 \%$ & $53.9 \%$ & $1.5 \triangle$ & & & & \\
\hline
\end{tabular}


〈표 5〉2개년간 DFID의 취약국 대상 프로젝트 예산 규모 및 순위

\begin{tabular}{|c|c|c|c|c|c|c|}
\hline \multirow[t]{2}{*}{ 번호 } & \multirow[t]{2}{*}{ 국가명 } & \multirow[t]{2}{*}{ 취약성 수준 } & \multicolumn{2}{|c|}{$\begin{array}{l}\text { 총 프로ㅈㅔㅔㅌㅡ 예산액 } \\
\text { (단위: 백만 달러) }\end{array}$} & \multicolumn{2}{|c|}{ 총 프로젝트 예산순위 } \\
\hline & & & FY16/17 & FY17/18 & FY16/17 & FY17/18 \\
\hline 1 & 파키스탄 & 높은 취약성 & 549.2 & 396.1 & 1 & 1 \\
\hline 2 & 에티오피아 & 중간 취약성 & 420.6 & 277.7 & 2 & 3 \\
\hline 3 & 나이지리아 & 중간 취약성 & 388.7 & 285.8 & 3 & 2 \\
\hline 4 & 시리아 & 높은 취약성 & 281.9 & 170.4 & 4 & 9 \\
\hline 5 & 시에라리온 & 낮은 취약성 & 267.4 & 141.7 & 5 & 13 \\
\hline 6 & 탄자니아 & ‘높은 취약성’ 국가 주변국 & 247.3 & 237.3 & 6 & 4 \\
\hline 7 & 요르단 & ‘높은 취약성’ 국가 주변국 & 234.7 & 63.8 & 7 & 20 \\
\hline 8 & 남수단 & 높은 취약성 & 222.1 & 194.2 & 8 & 5 \\
\hline 9 & 아프가니스탄 & 높은 취약성 & 215.6 & 162.4 & 9 & 10 \\
\hline 10 & 소말리아 & 높은 취약성 & 215.2 & 190.1 & 10 & 6 \\
\hline 11 & 방글라데시 & 중간 취약성 & 210.2 & 158.9 & 11 & 11 \\
\hline 12 & 사하라이남지역 & 취약 지역 & 205.3 & 84.3 & 12 & 15 \\
\hline 13 & $\mathrm{DR}$ 콩고 & 높은 취약성 & 193.9 & 170.7 & 13 & 8 \\
\hline 14 & 케냐 & 중간 취약성 & 184.0 & 171.5 & 14 & 7 \\
\hline 15 & 레바논 & 중간 취약성 & 150.9 & 73.0 & 15 & 17 \\
\hline 16 & 네팔 & 낮은 취약성 & 134.2 & 105.8 & 16 & 14 \\
\hline 17 & 짐바브웨 & 중간 취약성 & 120.5 & 58.8 & 17 & 22 \\
\hline 18 & 우간다 & 낮은 취약성 & 120.1 & 44.9 & 18 & 25 \\
\hline 19 & 이라크 & 높은 취약성 & 120.0 & 50.3 & 19 & 24 \\
\hline 20 & 버마 & 높은 취약성 & 114.2 & 72.8 & 20 & 18 \\
\hline 21 & 터키 & ‘높은 취약성’ 국가 주변국 & 110.4 & 157.5 & 21 & 12 \\
\hline 22 & 팔레스타인점령지역 & 중간 취약성 & 86.0 & 77.9 & 22 & 16 \\
\hline 23 & 예멘 & 높은 취약성 & 82.7 & 62.9 & 23 & 21 \\
\hline 24 & 르완다 & ‘높은 취약성’ 국가 주변국 & 76.0 & 55.3 & 24 & 23 \\
\hline 25 & 잠비아 & ‘높은 취약성’ 국가 주변국 & 64.8 & 70.7 & 25 & 19 \\
\hline 26 & 중동지역 & 취약 지역 & 24.5 & 9.3 & 26 & 27 \\
\hline 27 & 중앙아프리카공화국 & 높은 취약성 & 21.4 & 14.0 & 27 & 26 \\
\hline 28 & 우크라이나 & 낮은 취약성 & 16.7 & 2.5 & 28 & 31 \\
\hline 29 & 타지키스탄 & 중간 취약성 & 6.8 & 7.3 & 29 & 28 \\
\hline 30 & 라이베리아 & 낮은 취약성 & 5.9 & 4.2 & 30 & 30 \\
\hline 31 & 부룬디 & 높은 취약성 & 5.8 & 0.5 & 31 & 35 \\
\hline 32 & 리비아 & 높은 취약성 & 4.8 & 0.8 & 32 & 32 \\
\hline 33 & 키르기스스탄 & ‘높은 취약성’ 국가 주변국 & 4.0 & 5.8 & 33 & 29 \\
\hline 34 & 아이티 & 중간 취약성 & 3.8 & 0.1 & 34 & 36 \\
\hline 35 & 캄보디아 & 낮은 취약성 & 2.4 & 0.5 & 35 & 34 \\
\hline 36 & 말리 & 중간 취약성 & 0.4 & 0.6 & 36 & 33 \\
\hline \multicolumn{3}{|c|}{ 취약국/지역 대상 프로젝트 예산 총합(A) } & 5112.6 & $3,580.5$ & & \\
\hline \multicolumn{3}{|c|}{ DFID 전체 프로젝트 예산 총합(B) } & 12632.4 & $8,041.4$ & & \\
\hline \multicolumn{3}{|c|}{ 전체 프로젝트 예산 대비 취약국/지역 예산 비중(A/B) } & $40.5 \%$ & $44.5 \%$ & & \\
\hline \multicolumn{7}{|c|}{ 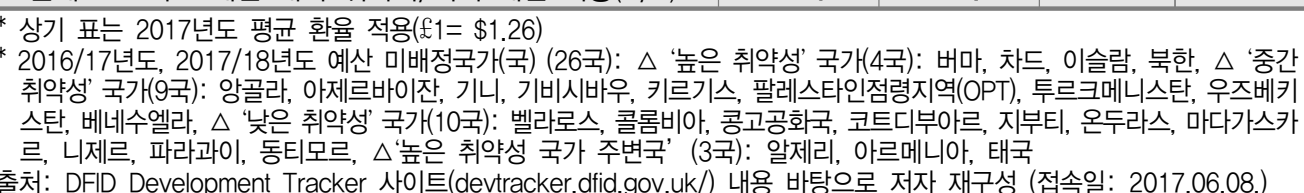 } \\
\hline
\end{tabular}

제 I 장 
또한 지난 2 개년간 $\mathrm{DFID}$ 로부터 최대 지원을 받은 상위 10 개 취약국가들을 보면 2014년도에는 10 개 중 파키스탄, 남수단, DR콩고 총 3국가가, 2015년도에는 남수단, 시리아, 아프가니스탄 등 총 3 국가만이 높은 취약성을 보일 뿐 나머지는 중간 또는 낮은 취약성을 보이고 있다는 점에서 취약성에 대한 적절한 진단을 바탕으로 지원 예산이 책정된 것인가에 대해서도 의구심이 제기된다.

상기 <표 5>는 2016/17년도 및 2017/18년도 DFID의 총 프로젝트 예산을 나타낸 표이다. 동 예산은 프로젝트 수준에서 이루어지는 회계 연도상의 예산이므로 $\mathrm{DFID}$ 의 예산의 일부라는 점, 회계연도 예산은 추후 변동 가능하다는 점에서 $\mathrm{DFID}$ 의 전체 예산 중 $50 \%$ 를 취약국에 지원한다는 목표를 가늠하기 위한 데이터로 보기에는 불충분하다. 하지만 분쟁 및 취약국 지원 은 일반적으로 프로젝트 차원에서 주로 이루어진다는 점에서 $\mathrm{DFID}$ 의 취약국가 및 지역에 대한 지원 흐름 및 추세를 파악하기에는 적절하다고 할 수 있다. 상기 예산 구성에서도 앞선 2014 15년도 지원액 추세와 마찬가지로 대상은 다르지만 총 26개 취약국가 및 지역이 예산 배정을 받지 못하였으며, 그 중에서 '높은 취약성(high fragility)'을 보임에 따라 지원이 시급한 국가들 또한 6 개국이 포함되어 있다. 아울러 예산 배정은 받고 있으나 그 규모가 너무도 작은 '높은 취약성' 국가들 또한 이전의 지원액 배정 추세가 크게 차이가 없다는 점에서 과연 $\mathrm{DFID}$ 의 신규 취약국가 및 지역 리스트 구성을 가지고 2020년까지 $\mathrm{DFID}$ 의 취약국 지원 예산을 증대시 킨다고 하여도 그 배정이 형평성 자체에도 의구심이 제기될 수밖에 없는 실정이다.

〈표 6〉 2014-2015 지원액 및 2016/17-2017/18년도 프로젝트 예산액 기준 상위 10대 취약 국가지역

\begin{tabular}{|c|c|c|c|c|}
\hline 순위 & 2014년 총 지원액 & 2015년 총 지원액 & $\begin{array}{c}2016 / 17 \\
\text { 프로젝트 예산총액 }\end{array}$ & $\begin{array}{c}2017 / 18 \\
\text { 프로젝트 예산총액 }\end{array}$ \\
\hline 1 & $\begin{array}{c}\text { 에티오피아 } \\
\text { (중간 취약성) }\end{array}$ & $\begin{array}{c}\text { 파키스탄 } \\
\text { (높은 취약성) }\end{array}$ & $\begin{array}{c}\text { 파키스탄 } \\
\text { (높은 취약성) }\end{array}$ & $\begin{array}{c}\text { 파키스탄 } \\
\text { (높은 취약성) }\end{array}$ \\
\hline 2 & $\begin{array}{c}\text { 파키스탄 } \\
\text { (높은 취약성) }\end{array}$ & $\begin{array}{c}\text { 에티오피아 } \\
\text { (중간 취약성) }\end{array}$ & $\begin{array}{c}\text { 에티오피아 } \\
\text { (중간 취약성) }\end{array}$ & $\begin{array}{c}\text { 나이지리아 } \\
\text { (중간 취약성) }\end{array}$ \\
\hline 3 & $\begin{array}{l}\text { 시에라리온 } \\
\text { (낮은 취약성) }\end{array}$ & $\begin{array}{c}\text { 나이지리아 } \\
\text { (중간 취약성) }\end{array}$ & $\begin{array}{c}\text { 나이지리아 } \\
\text { (중간 취약성) }\end{array}$ & $\begin{array}{c}\text { 에티오피아 } \\
\text { (중간 취약성) }\end{array}$ \\
\hline 4 & $\begin{array}{c}\text { 나이지리아 } \\
\text { (중간 취약성) }\end{array}$ & $\begin{array}{l}\text { 시에라리온 } \\
\text { (낮은 취약성) }\end{array}$ & $\begin{array}{c}\text { 시리아 } \\
\text { (높은 취약성) }\end{array}$ & $\begin{array}{c}\text { 탄자니아 } \\
\text { ('높은 취약성' 주변국) }\end{array}$ \\
\hline 5 & $\begin{array}{l}\text { 방글라데시 } \\
\text { (중간 취약성) }\end{array}$ & (높암수단 찬약성) & $\begin{array}{l}\text { 시에라리온 } \\
\text { (낮은 취약성) }\end{array}$ & $\begin{array}{c}\text { 남수단 } \\
\text { (높은 취약성) }\end{array}$ \\
\hline 6 & $\begin{array}{l}\text { 아프가니스탄 } \\
\text { (높은 취약성) }\end{array}$ & $\begin{array}{c}\text { 시리아 } \\
\text { (높은 취약성) }\end{array}$ & $\begin{array}{c}\text { 탄자니아 } \\
\text { ('높은 취약성' 주변국) }\end{array}$ & $\begin{array}{c}\text { 소말리아 } \\
\text { (높은 취약성) }\end{array}$ \\
\hline 7 & $\begin{array}{c}\text { DR콩고 } \\
\text { (높은 취약성) }\end{array}$ & $\begin{array}{c}\text { 탄자니아 } \\
\text { ('높은 취약성' 주변국) }\end{array}$ & $\begin{array}{c}\text { (요르닾안 } \\
\text { 취약성' 주변국) }\end{array}$ & $\begin{array}{c}\text { 케ㄴㅑㅑ } \\
\text { (중간 취약성) }\end{array}$ \\
\hline 8 & $\begin{array}{c}\text { 남수단 } \\
\text { (높은 취약성) }\end{array}$ & $\begin{array}{l}\text { 아프가니스탄 } \\
\text { (높은 취약성) }\end{array}$ & $\begin{array}{c}\text { 남수단 } \\
\text { (높은 취약성) }\end{array}$ & $\begin{array}{c}\text { DR콩고 } \\
\text { (높은 취약성) }\end{array}$ \\
\hline 9 & $\begin{array}{c}\text { 탄자니아 } \\
\text { ('높은 취약성’ 주변국) }\end{array}$ & $\begin{array}{c}\text { 방글라데시 } \\
\text { (중간 취약성) }\end{array}$ & $\begin{array}{l}\text { 아프가니스탄 } \\
\text { (높은 취약성) }\end{array}$ & $\begin{array}{c}\text { 시리아 } \\
\text { (높은 취약성) }\end{array}$ \\
\hline 10 & $\begin{array}{l}\text { 중동지역 } \\
\text { (취약 지역) }\end{array}$ & $\begin{array}{l}\text { 라이베리아 } \\
\text { (낮은 취약성) }\end{array}$ & $\begin{array}{l}\text { (소말리아 } \\
\text { (높은 취약성) }\end{array}$ & $\begin{array}{l}\text { 아프가니스탄 } \\
\text { (높은 취약성) }\end{array}$ \\
\hline
\end{tabular}

출처: 저자 작성

40 | 국제개발협력 
상기 <표 6>은 앞선 <표 4>와 <표 5>상의 DFID 취약국 대상 총 지원액과 프로젝트 예산 구성을 가지고 작성한 지원액(disbursement) 및 예산 배정액(commitment) 규모에 따 른 상위 10 대 취약국가 및 지역을 나타낸 표이다. 아래 표에서 보이는 바와 같이 DFID가 새로이 작성한 취약국 리스트 상에서 ‘높은 취약성’ 국가로 분류되었음에도 불구하고 예산지원 이 상위 10 개국에서는 4 5개국 정도만 꾸준히 상위권을 차지하고 있음을 알 수 있다.

〈표 7〉 2014, 2015 지원액 및 2016/17-2017/18년도 프로젝트 예산 기준 제외 취약국 명단

\begin{tabular}{|c|c|c|c|}
\hline 구분 & 2014년 총 지원액 & 2015년 총 지원액 & $\begin{array}{l}\text { 2016/17-2017/18 } \\
\text { 프로젝트 예산총액 }\end{array}$ \\
\hline \multirow{6}{*}{ 높은 취약성 국가 } & 차드 & 차드 & 차드 \\
\hline & 북한 & 북한 & 북한 \\
\hline & 버마 & 버마 & 라오스 \\
\hline & 이슬람 & 이슬람 & 튀니지아 \\
\hline & & 부룬디 & 이란 \\
\hline & & 에리트리아 & 에리트리아 \\
\hline \multirow{10}{*}{ 중간 취약성 국가 } & 앙골라 & 앙골라 & 앙골라 \\
\hline & 아제르바이잔 & 아제르바이잔 & 아제르바이잔 \\
\hline & 기니 & 기니 & 기니 \\
\hline & 기비시바우 & 기비시바우 & 기비시바우 \\
\hline & 키르기스 & 키르기스 & 키르기스 \\
\hline & 투르크메니스탄 & 투르크메니스탄 & 투르크메니스탄 \\
\hline & 우즈베키스탄 & 우즈베키스탄 & 우즈베키스탄 \\
\hline & 베네수엘라 & 베네수엘라 & 베네수엘라 \\
\hline & 팔레스타인점령지역 & 팔레스타인점령지역 & 이집트 \\
\hline & & 말리 & \\
\hline \multirow{12}{*}{ 낮은 취약성 국가 } & 벨라로스 & 벨라로스 & 벨라로스 \\
\hline & 콜롬비아 & 콜롬비아 & 콜롬비아 \\
\hline & 콩고공화국 & 콩고공화국 & 콩고공화국 \\
\hline & 코트디부아르 & 코트디부아르 & 코트디부아르 \\
\hline & 지부티 & 지부티 & 지부티 \\
\hline & 온두라스 & 온두라스 & 온두라스 \\
\hline & 마다가스카르 & 마다가스카르 & 마다가스카르 \\
\hline & 니제르 & 니제르 & 니제르 \\
\hline & 파라과이 & 파라과이 & 파라과이 \\
\hline & 동티모르 & 동티모르 & 동티모르 \\
\hline & & 모리타니아 & 모리타니아 \\
\hline & & & 카메룬 \\
\hline \multirow{3}{*}{$\begin{array}{c}\text { ‘높은 취약성’ } \\
\text { 주변국 }\end{array}$} & 알제리 & 알제리 & 알제리 \\
\hline & 아르메니아 & 아르메니아 & 아르메니아 \\
\hline & 태국 & 태국 & 태국 \\
\hline 취약 지역 & 사하라북방지역 & 사하라북방지역 & 사하라북방지역 \\
\hline
\end{tabular}

출처: 저자 작성 
또한 2014-15년도 총 지원액 및 2016/17-2017/18년도 프로젝트 예산 규모를 기준으로 일체의 지원 및 예산 배정에서 제외된 국가들을 정리하면 상기 <표 $7>$ 과 같다. 여기서 회색 처리된 국가들은 총 4 개년도 데이터 중에서 한 번도 $\mathrm{DFID}$ 의 지원 및 예산 배정을 받지 못한 국가들로서 총 23 개 국가와 1 개 지역을 들 수 있다. 동 표에서 알 수 있는 바와 같이 한번 지원대상에서 배제된 국가 및 지역은 지속적으로 우선순위에서 제외되고 있으며, 이로 인해 $\mathrm{DFID}$ 가 선정한 취약국 기준에 의거하여 취약성 해소 대상으로 인정받았음에도 불구하고 제대 로 된 지원이 이루어지지 못함에 따라 취약국 지원전략 자체의 효과성 및 적절성에 대해서도 의구심이 제기될 수 있는 것이다.

\section{〈그림 2〉 신규 취약국가/지역 리스트 대상 분야별 예산 구성}

\begin{tabular}{|c|c|c|c|}
\hline \multicolumn{4}{|c|}{ * 그 외 분야( $16 \%)$ 에 해당하는 세부 항목의 순서별 구성은 아래와 같음. } \\
\hline 항목 & 비율 & 항목 & 비율 \\
\hline 기타 사회적 인프라 및 서비스 & $4.8 \%$ & 산업 & $0.7 \%$ \\
\hline 수자원 & $2.3 \%$ & 기업활동 & $0.6 \%$ \\
\hline 환경 & $1.5 \%$ & 은행 업무 및 금융서비스 & $0.6 \%$ \\
\hline 농업 & $1.4 \%$ & 교통 & $0.5 \%$ \\
\hline 다부문 & $1.2 \%$ & 무역 & $0.3 \%$ \\
\hline 예산 & $1.1 \%$ & 통신 & $0.05 \%$ \\
\hline 미할당분 & $1.0 \%$ & 총합 & $16 \%$ \\
\hline
\end{tabular}

* 상기 내용은 DFID 2017/18 예산 기준으로 작성되었음.

출처: DFID Development Tracker 홈페이지 (https://devtracker.dfid.gov.uk) 바탕으로 저자 재구성 (접속일: 2017.06.09.) 
그렇다면 이러한 취약국가 및 지역 리스트에 대한 예산 배분을 분야별 차원으로 보았을 때, $\mathrm{DFID}$ 는 어떠한 분야를 중심으로 지원하는지에 대해 살펴보고자 한다. 상기 <그림 $2>$ 는 $\mathrm{DFID}$ 신규 취약국가 및 지역 리스트 상에 제시된 63개 국가 및 3개 지역에 할당된 2017/18년도 프로젝트 예산을 기준으로 분석해본 분야별 예산 구성안이다. 동 그림에서 볼 수 있는 바와 같이 취약국 지원 예산 중에서 가장 많은 비중을 차지하는 분야는 '재난(disaster) 감소'로서 총 $23 \%$ 를 차지한다. 그 외에도 분야별 지원 상위 5 대 분야를 보면 '재난 감소(23\%)'의 뒤를 이어 ‘정부 및 시민 사회(government and civil society) 강화’가 $17 \%$, '보건(health) 개선'이 $16 \%$, '기타(others)' $16 \%$, '교육(education) 개선'이 $12 \%$ 로 총 $84 \%$ 의 구성을 보인다. 이외에도 대상 취약국가 및 지역의 특성에 맞추어 미비한 규모이기는 하지만 다양한 '그 외 분야' 사업들이 이루어지고 있으며, 대표적으로는 '기타 사회적 인프라 및 서비스 개선 (4.8\%)', '수자원(2.3\%)', '환경(1.5\%)' 등 총 13 개의 추가 분야로 구성되어 있다(<그림 2>의 주석 참조).

이렇듯 $\mathrm{DFID}$ 의 경우 취약국가 및 지역 각각이 갖는 특수한 사정 및 상황을 고려하여 취약성 을 보이는 다양한 분야에 대해 적절한 프로젝트 사업을 기획 및 운영하고 있다. 하지만 문제는 동 프로젝트를 운영하는 대상이 되는 취약국가 및 지역 선정이 과연 적절하게 이루어졌냐이다. 높은 취약성을 보이는 국가일수록 보다 많은 규모의 원조가 이루어져야 함에도 불구하고 현실적 으로는 기존에 운영해오던 사업 대상 국가 및 사업 방식, 예산 규모 등이 큰 변화를 보이지 못한 기존대로 운영되는 상황을 보이고 있는 것이다. 


\section{III. 선진 공여기관의 분쟁· 취약국 측정 및 성과관리: DFID와 USAID 중심으로}

그렇다면 앞선 취약국가 및 지역에 대한 원조전략을 바탕으로 $\mathrm{DFID}$ 는 어떠한 성과 프레임워 크를 구축하여 모니터링 및 평가(Monitoring and Evaluation, M\&E)를 진행하고 있을까. 그런데 여기서 생각해야 할 것은, 취약국에 대한 성과관리 방식도 사실상 각 공여기관들에 따라 각 기관별로 가지고 있는 취약성(fragility) 또는 취약국(fragile states) 정의, 전략 및 기조 등의 설정 방향에 따라 그 모습을 달리하고 있다는 점이다. 따라서 OECD INCAF 및 뉴딜 등에서도 보다 표준화된 성과관리 지침을 제시하고자 하나, 사실상 공여기관들, 그 중에서 도 $\mathrm{KOICA}, \mathrm{DFID}, \mathrm{USAID}$ 등과 같은 양자 공여기관들에서는 이러한 공통된 지침을 고려하는 동시에 해당 기관의 전략 및 방향에 맞추어 성과관리 방안 및 프레임워크를 별도로 구축하고자 한다. 따라서 동 절에서는 여러 선진 공여기관들이 취약국의 성과관리를 위한 공통적으로 고려 하고 있는 $\mathrm{OECD}$ 의 취약성(fragility) 측정을 위한 $\mathrm{DFID}$ 의 성과관리 프레임워크 및 고려 가능한 지표풀을 소개한다. 또한 이와 함께 글로벌 취약성 해소에 활발한 활동을 하고 있는 또다른 주요 양자공여기관인 USAID의 분쟁 및 취약국의 거버넌스 분석을 위해 활용하고 있는 '취약성 프레임워크(fragility framework)' 및 성과관리 지표 운영 과정과 지표풀 등을 함께 살펴봄으로써 선진 공여기관들이 어떻게 분쟁 및 취약국 지원 사업 시 취약성을 평가하고 관리하는지에 대해 소개하고자 한다.

\section{DFID 분쟁 및 취약국 성과프레임워크 및 지표풀}

$\mathrm{DFID}$ 는 분쟁 예방 및 안보 강화를 위해 앞서 소개한 바와 같이 다양한 전략을 실시하고 있으며, 효과적인 분쟁 및 취약국 지원을 위해 다양한 성과관리 방안 및 지표도 개발하여 운영 중에 있다. $\mathrm{DFID}$ 는 취약성을 정치, 경제, 사회 등과 같이 단순히 프로그램 섹터(sector) 차원만 인식하지 않고 국별차원(country level)에서도 각각 평화구축 프레임워크를 구축하고자 한다. 이에 DFID는 지난 2009년 평화구축 및 국가건설 프레임워크(Peacebuilding and Statebuilding Framework, 이하 PBSB 프레임워크)를 구축하였으며, 이후 2012년에 '분쟁 및 취약국 상황에서의 성과관리 지침(Results in Fragile and Conflict-Affected States and Situations: How to note)'을 발간하여 실제 분쟁 및 취약국 소재 해외사무소들이 대상 국가사업의 성과관리 방안을 국별, 사업 차원으로 나누어 소개하고 있다.

먼저 $\mathrm{PBSB}$ 프레임워크에서는 분쟁 및 취약국 지원 시 국별 및 지역별 차원의 전체적인 
전략 및 목표 설정에 대해 소개하고, 분쟁 상황 및 취약성 해소를 위해 어떠한 개입이 필요하고 무엇을 우선적으로 해야할지에 대해 전략을 수립하는 방법을 제시하고 있다. 동 문서에 따르면 분쟁 및 취약국 대상 개입을 고려할 때에는 우선적으로 대상 국가의 특수한 상황에 대한 분석에 서부터 시작하여야 하며, 전체적인 차원에서 프레임워크 내 각각의 측면에 대한 고려가 전반적 으로 이루어져야 한다. 이를 통해 DFID는 평화구축 및 국가건설을 위한 4대 목표 및 전략을 수립하게 되며, 이 과정에서는 OECD가 2011년 발표한 '분쟁 및 취약성 상황에서의 국가건설 지원: 정책 차원 가이드라인(Supporting statebuilding in situations of conflict and fragility: policy guidance)'에서 제시하고 있는 분쟁 및 취약성 평가 시 고려해야 할 주요 원칙들에 대한 고려를 바탕으로 한다5).

제I장

다음으로 DFID는 분쟁 및 취약국에서의 성과관리 지침(2012)을 통해 PBSB 프레임워크를 국별 수준(country level) 및 사업 수준(program level)에서 활용함으로써 DFID 현지 사무소 들이 분쟁 및 취약국 상황에서의 성과관리를 보다 효과적으로 할 수 있는 방안에 대해 안내하고 있다. 동 지침에서의 주요한 점은 분쟁 및 취약국 모니터링 및 평가를 위한 지표(indicators) 수립 시, 'Do no harm' 원칙을 고려하는 동시에 '변화이론(theory of change)'에 근거하여 $\mathrm{DFID}$ 가 실시하는 프로그램이 분쟁 및 취약성 해소에 어떠한 영향을 미치는지 그 결과와 연결시켜 고려함으로써 사업 결과 및 타당성을 지속적으로 모니터링할 수 있도록 고려하였다는 점이다. 이를 위해 분쟁 및 취약국에서 활동하는 해외사무소에서는 '변화이론(theory of change)'을 활용 하여 분쟁 및 취약성에 대해 먼저 측정(assessment)하고, 그 결과를 바탕으로 사업 성과측정 단계에서 임팩트(impact) 지표로 연결시키는 것이 필요하다고 강조하고 있다. 이를 통해 사업 의 성과를 이루는 일련의 사슬(result chain)의 기반이 되는 주요 논리 흐름에 대한 분석적 설명(analytical explanation)을 변화이론을 통해 제시할 수 있기 때문에 이는 추후 사업 기획 시 개선사항 및 고려사항들을 도출하는데 좋은 기반이 될 수 있는 것이다.

$\mathrm{DFID}$ 의 PBSB 프레임워크는 사업 시행을 하는 섹터 차원 및 국별 차원 모두에서 사용할 수 있는 프레임워크이다. 동 프레임워크 작성 시에는 변화이론에 기반하여 각 프레임워크 단계 별 내용이 상호유기적으로 작동하도록 작성해야 하는데, 이를 위해 먼저 목표(objectives)단계 에서는 분쟁 및 취약국 정부의 주인의식(national ownership)을 저해하지 않도록 대상 정부의 주인의식 강화와 관련한 내용으로 설정해야 하며, 그 하단의 목표(target) 및 각 단계별 주요 목표(milestone) 또한 이에 기반하여 현실적으로 설정되도록 하는 것이 중요하다고 강조하고 있다. 특히 분쟁 및 취약국 내에서 실질적으로 의미있는 제도적 변화를 기대하기 위해서는

5) $\mathrm{OECD} \mathrm{DAC}$ 의 분쟁 및 취약국 평가를 위한 주요 원칙은 다음의 문서에서 확인하기 바란다: OECD DAC Evalnet. 2011. "Evaluating Donor Engagement in Situations of Conflict and Fragility" 
최소 15 30년 정도의 시간이 소요된다는 점에서 프로젝트 주기 및 소요 시간 등 설정 시에도 보다 현실적으로 계획하는 것이 중요하다(DFID, 2012).

이렇게 목표(goals)가 설정되고 나면, 국별 프로그램들이 얼마나 효과적으로 작동하여 분쟁 및 취약성 해소에 기여하였는지를 측정하는 것이 중요한데, 이를 위해서는 국별 수준의 취약성 평가 지표(country-level indicators)를 활용하여 측정 가능하다 (하단 <표 8> 참조). 현재 $\mathrm{DFID}$ 에서도 사업 단계에서의 모니터링을 위한 지표 개발의 필요성을 가지고 있으나, 현실적으 로 국별 수준의 지표를 활용하여 사업 수준의 취약성을 측정하고 있는 실정인 것이다.

또한 국별 수준 및 사업 수준에서 동일한 방식으로 측정된 지표를 동시에 사용할 수도 있다. 가령 정치합의 과정이 포용적(inclusive)으로 이루어지는지에 대한 국민들의 인식도를 측정하기 위해서는 여론조사(opinion poll) 방법을 활용할 수 있는데, 이는 사업 수준에서 정부의 역량강화 및 책무성 강화가 이루어졌는지에 대한 측정지표로 활용할 수 있는 동시에 국가 차원에서 정치합 의의 포용성 수준에 대한 국가의 개선 수준을 측정하는 지표로도 활용 가능한 것이다.

〈표 8〉DFID 분쟁 및 취약성 평가를 위한 국가 수준 지표풀(안)

\begin{tabular}{|c|c|c|}
\hline 목표 & 가능 지표 & 가능 지표출처 \\
\hline \multirow{12}{*}{$\begin{array}{l}\text { 분쟁 및 취약 } \\
\text { 성의 원인 및 } \\
\text { 효과 }\end{array}$} & • 무력충돌로 인한 사망자 수 (\#) & $\begin{array}{l}\text { Uppsala Conflict Data project } \\
\text { (updated annually) }\end{array}$ \\
\hline & • 인구 대비 실향민 수 (\#) & $\begin{array}{l}\text { UNHCR data } \\
\text { Media monitoring }\end{array}$ \\
\hline & - 폭력적 충돌에 대한 보도 수 (\#) & $\begin{array}{l}\text { Official data, where available, } \\
\text { UNODC data. }\end{array}$ \\
\hline & - 인구 10 만 명당 고의적 살인 피해자 수 (\#) & Official data, programme data \\
\hline & $\begin{array}{l}\text { - 소외계층의 본원소득(primary income)의 증가 } \\
\text { 율 (\%) }\end{array}$ & Official data, programme data \\
\hline & - 이동의 자유(예: 특정 도로에서의 교통체증) (\#) & $\begin{array}{l}\text { Official data, Minorities at Risk } \\
\text { (updated 3-yearly) }\end{array}$ \\
\hline & $\begin{array}{l}\text { - 정치 부문 또는 공공기관에서의 소수집단 및 여 } \\
\text { 성 구성원의 수 (\#) }\end{array}$ & $\begin{array}{l}\text { Existing development data, } \\
\text { including MDG indicators }\end{array}$ \\
\hline & $\begin{array}{l}\text { - 종교, 민족, 지역, 계급, 성별 등에 따른 기존 } \\
\text { 개발 지표 (예: 서비스 제공, 문해율, 모자보건, } \\
\text { 가계소득 수준 등) }\end{array}$ & Official data, programme monitoring \\
\hline & - 토지소유권 관련 분쟁 해결 사례수 (\#) & Monitoring of legislation \\
\hline & $\begin{array}{l}\text { - 실제 이행된 평화협정 대상, 헌법 차원의 변화 } \\
\text { (constitutional changes)가 제안된 비중 (\%) }\end{array}$ & Gini coefficient \\
\hline & - 불평등 측정 수치 (\#) & Opinion polls \\
\hline & - 분쟁 발발 가능성에 대한 대중의 인식 비중 (\%) & \\
\hline
\end{tabular}




\begin{tabular}{|c|c|c|}
\hline 목표 & 가능 지표 & 가능 지표출처 \\
\hline \multirow{9}{*}{$\begin{array}{l}\text { 포용적 } \\
\text { 정치 합의 }\end{array}$} & $\begin{array}{l}\text { - 엘리트가 사용하는 파벌적·배타적 언어 } \\
\text { (factional/exclusive language)의 정도 }\end{array}$ & $\begin{array}{l}\text { Failed States Index - measures } \\
\text { elite factionalisation (updated } \\
\text { annually) }\end{array}$ \\
\hline & - 정치적 합의 과정에 대한 소수집단의 포함 정도 & $\begin{array}{l}\text { State Fragility Index (updated } \\
\text { annually) }\end{array}$ \\
\hline & $\begin{array}{l}\text { - 선거 투표에 대한 소외계층 및 소수집단 인구의 } \\
\text { 참여 비율 (\%) }\end{array}$ & Official statistics, survey data \\
\hline & 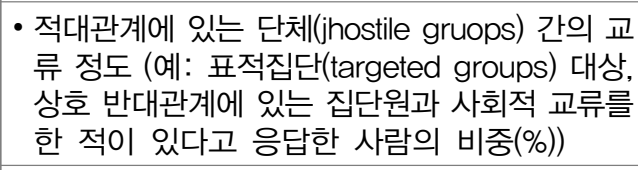 & $\begin{array}{l}\text { Programme / Survey Data, } \\
\text { Afrobarometer in some countries. }\end{array}$ \\
\hline & - 소수집단의 시민 · 정치 권리 수준 & $\begin{array}{l}\text { Freedom in the World (updated } \\
\text { annually) }\end{array}$ \\
\hline & $\begin{array}{l}\text { - 선거 및 정치 과정상의 공정성을 신뢰하는 인구 } \\
\text { 비중 (\%) }\end{array}$ & $\begin{array}{l}\text { Survey data, e.g. Gallup World } \\
\text { Poll, Afrobarometer where } \\
\text { available }\end{array}$ \\
\hline & - 정치합의의 포용성 증대를 위한 헌법 개정 유무 & Monitoring of legislation \\
\hline & $\begin{array}{l}\text { - 정치합의가 포용적으로 이루어진다고 인식하는 } \\
\text { 대중의 비중 (\%) }\end{array}$ & Opinion polls \\
\hline & $\begin{array}{l}\text { - 중앙 정당 및 지방 정당 구성원 중 배제집단 } \\
\text { (excluded groups) 출신의 성별, 인종별 참여 } \\
\text { 정도 }\end{array}$ & Party membership data \\
\hline \multirow{12}{*}{$\begin{array}{l}\text { 핵심 } \\
\text { 국가 기능 }\end{array}$} & $\begin{array}{l}\text { - 정부의 효과적인 영토통제력 가능 여부 (예. 주 } \\
\text { 요한 국내 안보 관련 사건 발생 건수) }\end{array}$ & Official data, media monitoring \\
\hline & $\begin{array}{l}\text { - 민간감시(civilian oversight) 통제를 받지 않고 } \\
\text { 이루어지는 민간치안서비스 사례 건수 (\#) }\end{array}$ & $\begin{array}{l}\text { Failed States Index (includes } \\
\text { measures of impunity etc.) }\end{array}$ \\
\hline & - 치안이 개선되었다고 인식하는 인구비중 (\%) & $\begin{array}{l}\text { Survey data, Gallup World Poll, } \\
\text { Afrobarometer, Opinion polls }\end{array}$ \\
\hline & - 경찰을 신뢰하는 인구 규모의 증가율 (\%) & Opinion polls \\
\hline & - 형사재판 비율 (전체 기소 건수 대비 비중) (\%) & Official data, UNODC. \\
\hline & $\begin{array}{l}\text { - 사법체계가 공정하고 효과적이라고 인식하는 } \\
\text { 인구 비중 (\%) }\end{array}$ & $\begin{array}{l}\text { Survey data, Gallup World Poll, } \\
\text { Afrobarometer, Opinion polls }\end{array}$ \\
\hline & - 효과적인 금융 및 거시경제관리 정도 & PEFA, CPIA scores \\
\hline & • 1인당 GDP & World Bank \\
\hline & - 지역별 GDP 기준 세수 비중 (\%) & Official statistics \\
\hline & - 전체 예산 중 천연자원으로 인한 소득 비중 (\%) & Official statistics \\
\hline & - 정규 급여를 받는 공공부문 근로자 비율 (\%) & Official statistics, survey data \\
\hline & $\begin{array}{l}\text { - 정부가 효과적으로 운영된다고 인식하는 인구 } \\
\text { 비중 (\%) }\end{array}$ & Opinion polls \\
\hline \multirow{2}{*}{$\begin{array}{l}\text { 국민의 기대에 } \\
\text { 대한 정부의 } \\
\text { 대응 }\end{array}$} & $\begin{array}{l}\text { - 정부의 기본 서비스 제공 정도에 대한 지역별, } \\
\text { 인종별, 지역별, 계층별, 성별 등 관련 기존 지표 }\end{array}$ & $\begin{array}{l}\text { Existing development data, } \\
\text { including MDG indicators }\end{array}$ \\
\hline & $\begin{array}{l}\text { - 공공 기관이 국민들의 편익을 위해 봉사한다고 } \\
\text { 믿는 인구비중 (\%) }\end{array}$ & $\begin{array}{l}\text { Survey data e.g. Gallup World } \\
\text { Poll, Afrobarometer, Opinion polls }\end{array}$ \\
\hline
\end{tabular}




\begin{tabular}{|c|c|c|}
\hline 목표 & 가능 지표 & 가능 지표출처 \\
\hline & • 금융접근성에 대한 국민의 인식 정도 (\%) & Survey data, Programme data \\
\hline & $\begin{array}{l}\text { - 소외계층의 본원소득(primary income) 증가율 } \\
\text { (\%) }\end{array}$ & Household survey \\
\hline & - 부패에 대한 인식 정도 (\%) & $\begin{array}{l}\text { Corruption Perceptions Index } \\
\text { Opinion polls. Also delegiti } \\
\text { misation score in Bertelsmann } \\
\text { Transformation Index (updated } \\
\text { biannually). Failed States Index }\end{array}$ \\
\hline & $\begin{array}{l}\text { - 정부의 정당성 정도 (예. 정부가 합법적으로 수 } \\
\text { 립되었으며 국민을 위해 제대로 기능한다고 인 } \\
\text { 식하는 인구의 증가율) (\%) }\end{array}$ & Open Budget Index \\
\hline & $\begin{array}{l}\text { - 인프라의 재건 또는 확장 정도 (예. 관개, 전기 } \\
\text { 등) }\end{array}$ & Local data \\
\hline & - 전체 국가예산 중 친빈곤적 예산 할당 비중 (\%) & Budget data \\
\hline
\end{tabular}

출처: DFID (2012)

$\mathrm{DFID}$ 는 분쟁 및 취약성 해소 경향을 모니터링하는데 유용한 기존의 다양한 데이터들을 활용하고 있으며, 이를 활용하여 기초선 정보(baseline information)을 수립하고자 한다. 대상 지표들은 반드시 변화이론에 기반하여 공여기관의 개입과 실시하는 프로그램이 분쟁 및 취약성 유발 요인(drivers)에 대해 어떠한 구체적인 성과(outcomes)로 연결되는지를 설명할 수 있어 야 한다고 강조한다. 또한 지표들은 반드시 이러한 성과(outcome)들을 모니터링할 수 있고 변화이론 자체의 유효성 또한 지속적으로 확인할 수 있도록 고안되는 것이 중요하다. 아울러 이러한 '평화구축 및 국가건설'과 관련한 지표들은 필요에 따라 각 섹터의 주요 목표(key sector objectives)들 또한 모니터링 할 수 있는 지표들로 구성되는 것이 중요하다. 가령 교육프로그램 의 경우 본래는 초등학교에 다니는 아동 수 증대를 목표로 하지만, 이는 국가 차원에서 보았을 때 소외집단 아동들의 초등교육 서비스 지원받도록 함으로써 국가의 정당성(legitimacy) 증대 를 측정하는 지표로 고안될 수도 있는 것이다. 이렇듯 지표는 표적 집단(target population) 구성을 어떻게 하는지에 따라 국가에 대한 국민들의 입장 변화 등을 반영하여 구성할 수도 있다. 이를 위해서는 초등학교에 다니는 아동의 전체 수에서 소외계층 아동의 수로 세분화 (disaggregation)하는 작업이 가능해야 한다.

이 과정에서 $\mathrm{DFID}$ 는 지표 선정 시 데이터의 이용가능성(data availability)가 중요한 요소 이기는 하지만 이것이 유일한 절대적인 기준이 되어서는 안 된다고 강조한다. 특히 분쟁 및 취약국의 상황에서는 측정 데이터의 이용가능성이 기본적으로 낮은 것이 일반적이기 때문에 측정의 용이성보다는 무엇을 측정해야 하는지 그 대상에 초점을 맞추는 접근이 필요한 것이다. 
따라서 이 과정에서 발생하는 데이터 갭(data gap)을 해결하기 위해서는 공식적인 지표뿐만 아니라 비공식적인 정보원 또한 고려할 수 있으며, 데이터 수집을 위해 전문인력의 역량 강화가 필요하다면 이를 위한 교육 지원 실시 등 다양한 방법 또한 이루어질 수 있다.

$\mathrm{DFID}$ 의 실제 분쟁 및 취약국에서의 사업운영 및 성과관리 방안과 관련하여 2012년 2017년 간 파키스탄 펀잡주(Punjab)와 카이버파크툰크와주(DPD)에 위치한 45 개 지역의 4,500 개 마 을에서 시행된 'AAWAZ Voice and Accountability Programme' 사례를 들 수 있다. 동 사업운영 및 성과관리에 대한 상세 내용은 <Annex $3>$ 을 참조하기 바란다.

\section{USAID 취약성 프레임워크 및 지표풀}

먼저 USAID의 분쟁 및 취약국의 거버넌스 측정 및 관리를 위한 방법을 알아보기 이전에 동 기관이 정의하는 분쟁 및 취약국의 정의를 살펴볼 필요가 있다. USAID는 취약국가(fragile states)의 범위를 실패한 국가(failing and failed states)에서 취약성을 회복하고 있는 국가 (recovering states)에 이르기까지 넓은 범위로 사용하고 있다. 특히 USAID는 대상 국가 가 실패하였다는 것보다 안정권으로 진입하기 위해 얼마나 오랜 시간이 추가로 소요될지에 대한 파악이 중요하다고 인식하고 있으며, 이로 인해 USAID는 분쟁 및 취약국 구별을 위해 이미 위기에 있는 국가(in crisis)와 취약성(fragility)을 지닌 국가로 구분하여 접근하 고 있다.

미국은 대외원조정책을 자국의 안보로부터 거의 분리하지 않고, 외국의 취약성(fragility)을 국내적 관심과 명시적으로 연결시키고 있음. USAID의 업무는 미국 안보 목적의 지원에 의하여 부분적으로 정당화되어 오고 있음 (권혁주, 2011) 평화구축 및 안보를 취약국 지원의 목표로 하던 $\mathrm{DFID}$ 와 달리, $\mathrm{USAID}$ 의 경우에는 경제개발과 굿거버넌스 구축 및 글로벌 차원의 안보 강화를 분쟁 및 취약국 지원의 주요 목표로 하고 있다.

또한 USAID는 취약국의 상황을 분석하고 모니터링하기 위해 취약성 프레임워크(fragility framework)를 사용하고 있다. 동 프레임워크에서는 정치, 경제, 사회, 안보 분야의 거버넌스를 효과성(effectiveness)과 정당성(legitimacy)를 기준으로 분석하여 작성되는데,6) 이러한 프

6) USAID는 취약성 프레임워크 내에서 효과성(effectiveness)과 정당성(legitimacy)를 다음과 같이 정의하고 있다. 먼저 효과성(effectiveness)란 공공재 및 공공 서비스를 비롯해 사회규율이 효과적으로 전달 및 운영될 수 있도록 하는 정부의 역량을 말하며, 정당성(legitimacy)이란 정부가 합리적이고 공평하게 국가의 권력을 행사하는 동시에 국가 전체 차원에서 이익을 위해 권력을 행사한다고 간주하는 사회구성원들의 인식을 의미한다. (출처: USAID, 2005a) 
레임워크를 사용함으로써 취약국의 상황을 다면적으로 분석함으로써 취약국의 현실을 반영하 는 우선순위를 고려하여, 해당 취약성의 원인 해결에 중점을 둔 프로그램을 적시에 보다 효과적 으로 운영할 수 있도록 하고자 한다(USAID, 2005). 아래의 <표 9>은 USAID가 취약성 프레임워크에서 각 주요 분야별로 효과성 및 정당성을 평가하는 기준이다.

〈표 9〉 취약국 거버넌스 분석: 취약국 프레임워크

\begin{tabular}{|c|c|c|}
\hline 분야 & 효과성(effectiveness) & 정당성(legitimacy) \\
\hline 정치 & $\begin{array}{l}\text { 정치 제도 및 정치 과정이 제대로 작동함으 } \\
\text { 로써 책무성을 보장하고 국민들의 수요를 } \\
\text { 충족할 수 있도록 적절히 자원을 분배할 수 } \\
\text { 있다. }\end{array}$ & $\begin{array}{l}\text { 정치 제도 및 정치 과정이 투명하고 사회적 } \\
\text { 가치를 존중하며 특정 집단의 이익을 편향되 } \\
\text { 게 보장하지 않도록 운영된다. }\end{array}$ \\
\hline 안보 & $\begin{array}{l}\text { 국경 수비 및 범죄 예방을 위해 군복무를 } \\
\text { 실시하고 치안 서비스를 제공한다. }\end{array}$ & $\begin{array}{l}\text { 군복무 및 치안 서비스가 모두에게 동등하 } \\
\text { 게 적용 및 제공되며 시민권을 침해하지 } \\
\text { 않는다. }\end{array}$ \\
\hline 경제 & $\begin{array}{l}\text { 경제 성장 제도를 통해 외부로부터의 충격 } \\
\text { 으로부터 내부 경제를 보호하고 경제적 변 } \\
\text { 화에 대한 적응력을 강화한다. }\end{array}$ & $\begin{array}{l}\text { 경제 성장 및 변화로 인해 발생하는 수익 및 } \\
\text { 비용을 동등하게 분배하여 적용한다. }\end{array}$ \\
\hline 사회 & $\begin{array}{l}\text { 취약계층 및 소수집단의 특별한 수요 또한 } \\
\text { 충족시킬 수 있는 법적 안전조치 및 사회서 } \\
\text { 비스를 제공한다. }\end{array}$ & $\begin{array}{l}\text { 관습, 문화, 신념 등과 관련한 집단에게도 동 } \\
\text { 등한 기회를 제공하는 등 다양성에 대한 관 } \\
\text { 용(tolerance)을 제고한다. }\end{array}$ \\
\hline
\end{tabular}

출처: USAID (2005b)

상기 취약국 프레임워크 내 각 분야별 효과성 및 정당성 기준에 맞추어 USAID는 취약국 성과관리를 위한 지표를 선정한다. USAID가 프레임워크 내 지표를 선정하기 위해서는 크게 4단계를 거쳐 진행한다. 먼저 잠재지표(potential indicators) 풀들을 최대한 수집하고(1단계), 그 다음으로 각 공여기관 내 사업 활동(activity) 및 사업목적(objectives) 등에 대해 관련된 잠재지표들을 매칭하는 작업을 실시한다(2단계). 그리고 난 후 협의를 통하여 지표와 사업의 연관성, 적절성, 배치 위치 등에 대해 논의한 후 최종지표로 고려 가능한 대상지표들을 선별해내 는 작업을 한다(3단계). 그러고 나서 대상지표들에 대한 데이터 이용가능성(data availability) 를 최종적으로 분석함으로써 최종지표로 선정하게 된다(4단계). 그렇다면 각 1 단계에서의 잠재 지표 선정 기준 및 3,4 단계에서의 최종지표 선정 기준은 어떻게 될까. 이는 아래<표 $10>$ 와 같다. 
〈표 10〉 USAID 취약국 프레임워크 내 지표 선정 및 점수화 기준

\begin{tabular}{|c|c|c|}
\hline \multicolumn{3}{|c|}{ 1단계: 취약국 성과관리 잠재 지표 선정 기준 } \\
\hline 번호 & 구분 기준 & 세부내용 \\
\hline 1 & $\begin{array}{l}\text { 데이터 포함범위 } \\
\text { (Data coverage) }\end{array}$ & $\begin{array}{l}\text { 지표 선정에 있어 사용될 데이터는 '포함범위가 넓어야 하고 오랜 } \\
\text { 시일 간 정기적으로 수집이 가능'해야 한다. 따라서 지역(regions) } \\
\text { 및 시간(time)' 두 측면 모두에서 포함범위가 충분하다고 판단되는 } \\
\text { 지표를 선정해야 한다. }\end{array}$ \\
\hline 2 & $\begin{array}{l}\text { 데이터 품질 } \\
\text { (Data quality) }\end{array}$ & $\begin{array}{l}\text { 지표 선정 시에는 데이터의 품질과 관련한 다양한 측면을 모두 고려 } \\
\text { 하여야 한다. }\end{array}$ \\
\hline 3 & $\begin{array}{l}\text { 국민차원의 연관성 } \\
\text { (Citizen relevance) }\end{array}$ & $\begin{array}{l}\text { 지표 선정 시에는 지표가 각국 시민들이 자국의 거버넌스가 갖는 } \\
\text { 효과성(effectiveness)과 정당성(legitimacy)에 대해 판단할 수 있는 } \\
\text { 적절한 판단 기반으로서 작용할 수 있도록 해야 한다. 가령, 영아치사 } \\
\text { 율(infact mortality), 인플레이션(inflation) 등은 사회 소속원 모두에 } \\
\text { 게 영향을 미칠 수 있다. 따라서 영아사망률 또는 인플레이션률 증대 } \\
\text { 등과 같은 현상은 해당 국가의 보건서비스 제공(health service } \\
\text { delivery) 또는 경제 관리(economic management) 등의 효과성 } \\
\text { (effectiveness)에 대한 국민들의 의견에 영향을 미칠 수 있다. }\end{array}$ \\
\hline 4 & $\begin{array}{l}\text { 원조사업과의 연관성 } \\
\text { (Programming } \\
\text { relevance) }\end{array}$ & $\begin{array}{l}\text { 지표 선정 시에는 대상지표가 해당 원조기관이 원조사업의 성과가 } \\
\text { 저조한 국가들에 대한 지원전략과 얼마나 잘 유기적으로 연계되어 } \\
\text { 있는지 또한 고려하여야 한다. }\end{array}$ \\
\hline \multicolumn{3}{|c|}{ 3,4단계: 최종지표 선정 시 고려 기준 } \\
\hline 번호 & 구분 기준 & 세부내용 \\
\hline 1 & 연관성(Relevance) & dimension)에 대해 계량적으로 얼마나 연관 \\
\hline 2 & $\begin{array}{l}\text { 국가포함범위 } \\
\text { (coverage) }\end{array}$ & 지표가 포함하는 국가의 수 \\
\hline 3 & $\begin{array}{l}\text { 시기상의 격차(lag } \\
\text { period) }\end{array}$ & $\begin{array}{l}\text { 지표의 발표(publication) 시점과 지표 관찰 시점 간에 발생하는 시기 } \\
\text { 상의 격차. 가령 특정 국가에 대해 2001년도 상의 특징을 반영한 } \\
\text { 지표가 2003년도에 실제 발표되었다면, 발표 시점에서 보면 2년간 } \\
\text { 의 시기상의 격차가 발생. }\end{array}$ \\
\hline 4 & 권위(authority) & $\begin{array}{l}\text { 지표가 해당 분야에서 얼마나 권위 있는 기관이나 개인으로부터 만 } \\
\text { 들어졌는지에 대한 정도. 가령 지표는 UNDP, World Bank, 등과 } \\
\text { 같은 기관을 통해서 또는 전문 개인 연구진을 통해 만들어질 수 있음 }\end{array}$ \\
\hline 5 & 강건성(Robustness) & $\begin{array}{l}\text { 지표의 결과가 외부 영향 및 변화에 크게 영향을 받지 않돌수록 좋은 } \\
\text { 지표라고 할 수 있음. }\end{array}$ \\
\hline \multicolumn{3}{|c|}{ 지표 점수화 기준 } \\
\hline 1 & 매우 우수(excellent) & 지표를 바로 사용 가능하며, 지표 개선 작업은 별로 요구되지 않음. \\
\hline 2 & 우수(good) & 지표를 바로 사용 가능하지만, 어느 정도 지표 개선 작업도 가능함 \\
\hline 3 & 수용 가능(acceptable) & $\begin{array}{l}\text { 지표를 일차적으로는 사용 가능하나, 기관의 전략에 맞추어 재편 } \\
\text { 작업이 필요함. }\end{array}$ \\
\hline 4 & 부족(deficiencies) & $\begin{array}{l}\text { 데이터의 불충분성으로 인해 일차적 사용이 어려우며, 지표 사용 } \\
\text { 이전에 어떠한 부분이 불충분한지에 대한 검토작업이 필수적으로 } \\
\text { 요구됨. }\end{array}$ \\
\hline
\end{tabular}

출처: USAID (2005b) 내용 바탕으로 저자 재정리 
동 표에서와 같이 USAID는 먼저 잠재지표군(potential indicators)를 수집할 때에는 $\triangle$ 데 이터가 가급적 넓은 지역 범위(regions)를 대상으로 오랜 시간에 걸쳐 정기적으로 수집이 가능 한지와 $\triangle$ 데이터의 신뢰도는 높은지, $\triangle$ 그리고 대상지표를 선택 시 해당 국가의 국민들이 동 지표를 통해 자국 정부의 거버넌스가 갖는 효과성(effectiveness) 및 정당성(legitimacy) 정도 가 어떠한지를 판단할 수 있는 기반이 될 수 있는지를 함께 살펴보아야 한다. 아울러 마지막으로 $\triangle$ 동 지표가 원조 기간이 실시하려고 하는 사업과 유기적으로 연계되어 있는지 또한 종합적으로 고려해야 한다.

그리고 이를 통해 수집된 잠재지표 중에서 최종지표를 선정하려고 할 때는 총 5 가지의 데이터 기준을 적용할 것을 권고하고 있다. 먼저 $\triangle$ 대상지표가 측정하려고 하는 내용을 계량 적으로 얼마나 연관성 있게 잘 나타내는지, $\triangle$ 그리고 지표가 포함하고 있는 국가의 수는 얼마나 되는지, $\triangle$ 그리고 지표의 발표 시점과 동 지표를 활용하려고 하는 시점 간에 발생하는 격차에 대한 조정 방안, $\triangle$ 얼마나 권위 있고 신뢰할 수 있는 기관으로부터 생성된 지표인지 여부, $\triangle$ 그리고 마지막으로 대상 지표가 외부적인 영향 및 다른 변화 상황에 따라 크게 결과가 바뀌지 않는 지표인지의 여부 등을 종합적으로 최종 고려하도록 한다. 또한 USAID는 이러한 잠재지표 및 최종지표의 선정 고려 기준에 대한 소개와 함께, 최종 선정된 최종지표를 점수화 하기 위한 기준 또한 함께 소개하고 있다. 점수화 결과는 '매우 우수(excellent)', '우수 (good),' '수용가능(acceptable),' '부족(deficiencies)' 등 총 4개의 점수 기준으로 작성되며, 각 최종지표에 대한 점수화 결과는 아래 표인 <표 $11>$ 에 종합적으로 정리되어 있으므로 참조하기 바란다. 


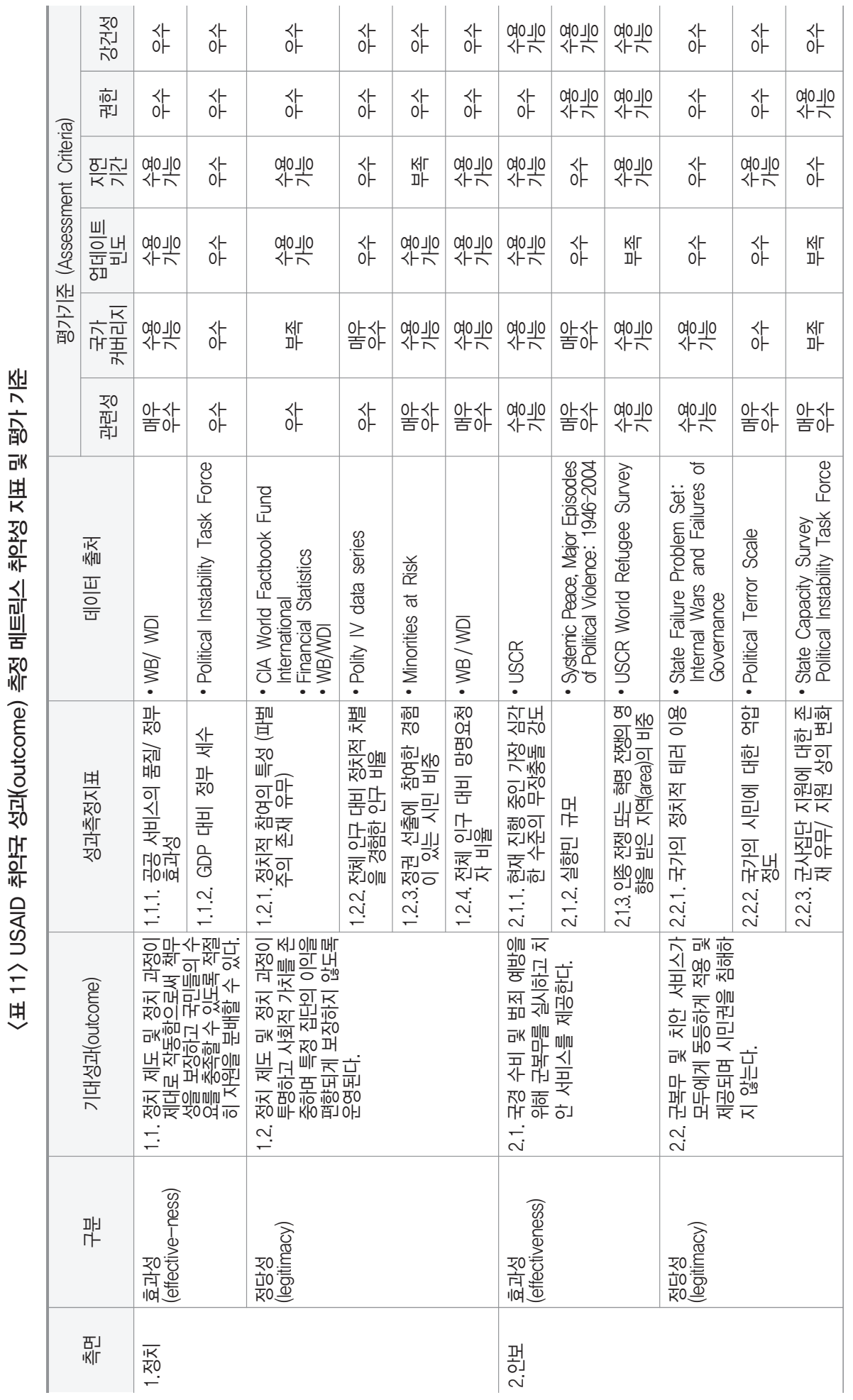

제 I 장

개

발

협

력

이

슈

제II장

제표장 


\begin{tabular}{|c|c|c|c|c|c|c|c|c|c|c|c|c|c|}
\hline \multirow{6}{*}{ 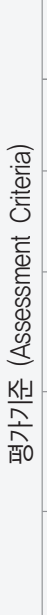 } & 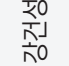 & 사 & 아 & 아 & $\begin{array}{l}\text { Kir } \\
\text { 마 }\end{array}$ & 여에이 & 아 & 사 & 사 아 & 영에인 & 여에니 & 아 & 아 \\
\hline & 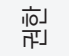 & 나 & $\begin{array}{l}\text { ㄴ } \\
\text { of }\end{array}$ & 나 & 라 & 사 & 나 & 사 & 라 & 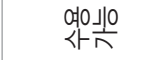 & $\begin{array}{l}\text { 여ㅇㅔㅔㅇㅣ } \\
\left\langle<\frac{1}{n}\right.\end{array}$ & 라 & 사 \\
\hline & $\frac{\bar{\delta}}{K} \frac{\hat{\lambda}}{\Lambda}$ & $\begin{array}{l}\text { KसI } \\
\text { II }\end{array}$ & of & of & $\begin{array}{l}\text { KMI } \\
\text { I- }\end{array}$ & 여욕에 & 연 & $\begin{array}{l}\text { Kkr } \\
\text { I- }\end{array}$ & 여요시 & 아 & 나 & 아 & 아 \\
\hline &  & 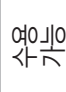 & 나 & 사 & $\begin{array}{l}\mathrm{K} / \Gamma \\
\text { 마 }\end{array}$ & 나 & 싸 &  & 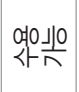 & 나 & 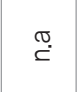 & 싸 & 라 \\
\hline & 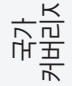 & 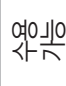 & 라 & 연에넹 &  & $\begin{array}{l}\text { 영에이 } \\
\left\langle\vdash \frac{1}{n}\right.\end{array}$ & 연 & 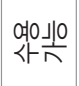 & $\begin{array}{l}\text { 영에이 } \\
\left\langle\vdash \frac{1}{n}\right.\end{array}$ & 아 & $\begin{array}{l}\text { 여에이 } \\
\left\langle\vdash \frac{1}{n}\right.\end{array}$ & 나 & 라 \\
\hline & 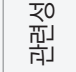 & 아ㅁㅏㅏㅁㅏ & 아 & 아 & 암다 & $\begin{array}{l}\text { 여에이 } \\
\left\langle<\frac{10}{n}\right.\end{array}$ & 역에인 & 앟사 & 앟사 & 암사 & $\begin{array}{l}\text { 영에이 } \\
\left\langle\vdash \frac{1}{n}\right.\end{array}$ & 사 & 아 \\
\hline &  & 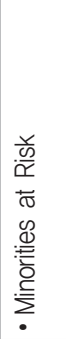 & 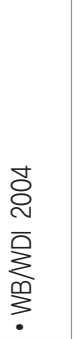 & & 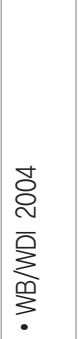 & 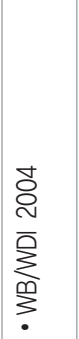 & 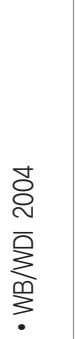 & 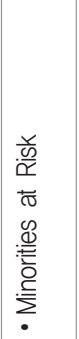 &  & 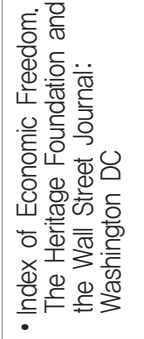 & $\begin{array}{l}\frac{\bar{a}}{3} \\
\frac{m}{3} \\
\underline{.}\end{array}$ & $\begin{array}{l}\frac{\bar{p}}{3} \\
\frac{m}{3} \\
\underline{0}\end{array}$ & 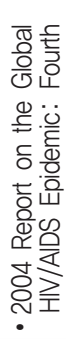 \\
\hline & 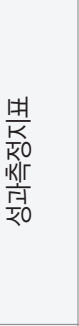 & 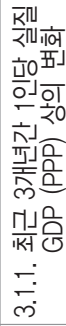 &  & 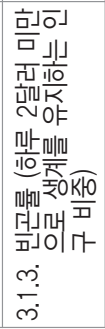 & 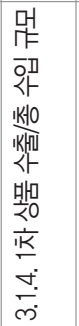 & 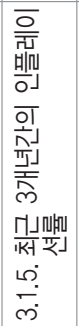 & 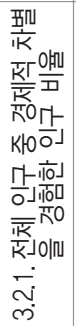 & 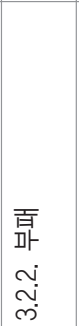 &  & 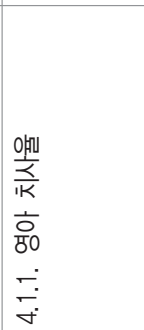 &  & 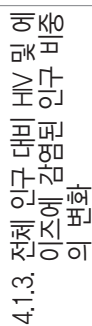 &  \\
\hline & 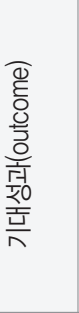 & 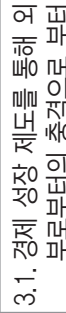 & 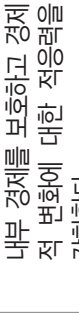 & & & & 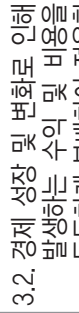 & 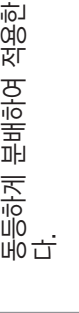 & & 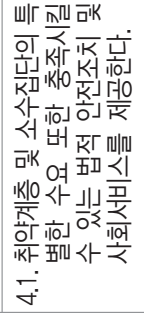 & & & \\
\hline & 郘 & 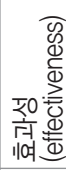 & & & & & 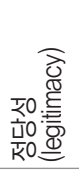 & & & 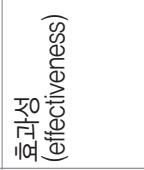 & & & \\
\hline & |k| & 员 & & & & & & & & 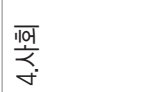 & & & \\
\hline
\end{tabular}






제 I 장

개

발

협

력

이

슈

제II장

제피장 


\section{IV. 한국 및 KOICA 분쟁·취약국 지원을 위한 시사점}

\section{1. 원조 규모 확대(scale-up) 및 범부처 간 참여의 필요성}

취약국에 대한 국제적 차원의 전체 ODA 비중은 지속적으로 하락하고 있다. $\mathrm{OECD}$ 취약국 리스트 기준, 2011년도에는 취약국에 대한 글로벌 ODA 지원 규모는 2010년 대비 $2.4 \%$ 하락하 였으며, 이후 최근 5년간 취약국에 대한 원조 규모 재조정 및 감소에 대한 많은 양자원조기관들 의 정치적, 경제적 압박이 존재해온 것이 사실이다. 특히 취약국에 대한 원조의 경우 그 자체가 외교안보적으로 민감한 이슈로서 국가 간 정책 방향 및 취약국가 내 존재하는 많은 변수로 인해 그 변동성(volatility)이 매우 심한 경향이 존재한다는 점에서 취약국에 대한 지원원조는 쉽지 않은 것이 사실이다. 이로 인해 취약국 대상 글로벌 ODA 지원 규모는 2011년 대비 2012년도에 25\% 폭등하였다가 2013년에는 다시 4\% 감소하는 등 매우 큰 변동 폭을 보인다 (ICAI, 2015). 하지만 이러한 와중에 지속적으로 분쟁 및 취약국에 대한 지원 예산 규모를 증대하고 있는 대표적인 두 공여기관이 바로 $\mathrm{DFID}$ 와 USAID이다. 특히 $\mathrm{DFID}$ 는 2015 新영국 원조전략에 따라 2020년까지 DFID 전체 예산 대비 50\% 이상을 분쟁 및 취약국에 지원하는 동시에 취약국 지원을 위한 범부처 차원의 기금도 신규 설립하여 취약국 지원을 위한 예산 마련에도 적극적으로 참여하고 있다.

이러한 점과 비교해보았을 때 한국은 2015년 기준 전체 양자 ODA의 약 $30 \%$ 를 분쟁 및 취약국에 지원하는 동시에, $\mathrm{UN}$ 을 중심으로 추진되는 국제사회의 분쟁 예방 및 해결에 주도적으 로 참여하며 재정지원 규모 확대에 기여하고 있다. 현재 한국 내에서는 영국의 사례와 같은 범부처 차원의 분쟁 및 취약국 지원 기금이 별도로 마련되어 있지는 않으나, 대신 세계은행 경제평화구축기금(Korea Trust Fund for Economic and Peace Building Transitions)을 통해 체제 전환국의 거버넌스 구축 및 이들 국가의 경제 재건과 발전을 지원하는 사업에 지원하 고 있다. 이러한 한국 정부의 노력에 발맞추어 KOICA 또한 개발협력 및 인도적 지원 양 측면에서 모두 소외된 취약국에 대한 특별지원을 위한 '취약국 지원 예산'을 별도로 마련 (2017 년 기준 약 108 억 원 규모)하여 지원지침에 따라 집행 중에 있다.

이렇듯 한국 또한 분쟁 및 취약국에 대한 지원을 인도적 지원과 연계하여 별도의 예산을 책정하고 운영 중에 있으나, 사실상 분쟁 및 취약국의 특수성상 단순히 개발 차원에서 외교부 또는 KOICA 주도의 사업이 이루어져서는 실질적인 취약성 해소가 쉽지 않은 것이 사실이다. 물론 유무상 원조를 주로 담당하고 있는 시행기관이 중심적인 역할을 해야 하는 것은 맞지만, 
안보 및 국방 등 그 자체가 갖는 국익 차원에서의 민감성을 고려하였을 때는 단순히 개별 부처 차원에서 원조가 이루어지는 것 보다는 국제개발협력의 기본법을 중심으로 범부처 간의 분쟁 및 취약국 지원 기금을 마련하여 보다 다각적인 고려 및 참여를 바탕으로 한 종합적인 지원전략이 마련될 필요가 있다. 아직은 한국의 분쟁 및 취약국 지원을 위한 예산 마련이 초기 단계에 있기 때문에 대상 지역에 대한 원조 규모 확대 및 범부처 간의 공통 지원 기금 마련 등은 앞으로 $\mathrm{KOICA}$ 를 비롯한 한국 정부가 종합적으로 노력해나가야 할 부분일 것이다.

\section{2. 분쟁 및 취약국 지원전략 내 성과관리 프레임워크 구축 필요}

영국의 원조전략(UK Aid)와 마찬가지로, 한국에서도 ‘국제개발협력기본법’이 존재하며, 그

목표 중 하나로 개도국의 빈곤감소와 삶의 질 향상을 명시하고 있다. 최근 수립 중에 있는 '제 2차 개발협력기본계획(2016-2020)' 역시 한국의 개발협력이 취약계층과 소외계층에 대한 배려를 구현하고자 하는 SDGs 달성에 기여하기 위한 것임을 비전으로 제시하고 있다.

아울러 현재 외교부 차원에서도 '분쟁 및 취약국 전략'을 수립 중에 있으며, 이 가운데 KOICA 또한 2017년 상반기에 ‘취약국 지원을 위한 중기이행전략(2017-2019)'을 수립하고 $\mathrm{KOICA}$ 가 정의하는 취약국의 정의 및 지원원칙, 지원대상 취약국 리스트, 지원 추진 전략 등을 종합적으로 제시하고 있다. 이는 상기에서 언급한 바와 같이 2015년 분쟁 및 취약국 지원 을 위한 KOICA 예산 88억 원을 신설한 데 이어 2017년 그 지원 규모가 108 억 원으로 증대됨에 따라 동 예산의 효과적인 운용을 위해서라도 매우 시의적절한 필요한 전략이며 $\mathrm{KOICA}$ 가 무상원조전담기관으로서 앞으로의 분쟁 및 취약국 지원을 위한 ODA 지원과 관련하여 국내 타 부처들에 방향 제시 및 안내자로서 역할이 요구된다는 점에서 보았을 때 동 전략 수립 자체가 갖는 의미는 크다고 할 수 있다.

이렇게 $\mathrm{KOICA}$ 차원에서의 취약국 지원을 위한 전략을 수립하고 분쟁 및 취약국 예산 또한 증대되어 감에 따라 동 기조에 따른 분쟁 및 취약국 대상 사업운영에 대한 성과관리 방안 마련 또한 중요한 이슈로 제기된다. 하지만 현재 $\mathrm{KOICA}$ 의 취약국 지원 전략상에서는 분쟁 및 취약국의 지원 성과관리 방안은 배제되어 있으며, 동 부분은 앞으로 KOICA가 보완해나가야 할 지점이라고 할 수 있다. 특히 $\mathrm{KOICA}$ 의 취약국 지원전략에서는 취약국 지원을 단기, 중기, 장기적 차원에서 연계하여 운영할 것을 권고하고 있으며, 동 전략을 사업에 적용한 이후 동 전략의 개선사항에 대한 환류 계획을 2019년 정도로 감안하고 있다는 점에서, 향후 효율적인 환류 과제 수행을 위해서도 그 전에 취약국 지원사업을 위한 성과관리 방향을 제시할 필요가 있다. 아울러 취약국 이슈 자체가 범분야 이슈라는 점에서, 단순히 취약국 지원을 위한 별도의 
사업으로 운영되기보다는 일반 사업에 접목시켜 지원이 이루어질 수도 있다는 점에서 KOICA 의 취약국 지원 자체를 위한 개별성과 프레임워크에 대한 구축과 함께 KOICA 주요 5대 분야별 사업의 성과지표 등과의 연계성 분석을 통한 접목 가능성에 대해서도 분석작업이 이루어질 필요가 있다.

이렇듯 분쟁 및 취약국 지원은 단순히 글로벌 차원의 평화 및 안보 구축을 위한 노력일 뿐만 아니라, 이를 통해 자국의 평화 및 안보, 번영을 통한 자국 이익을 강화하는 기반이 된다고 할 수 있다. 이에 $\mathrm{KOICA}$ 를 비롯한 한국 정부 또한 전세계 취약계층 및 소외계층에 대한 지원과 평화구축에 대해 기여함으로써 국제 주요한 공여기관으로서의 입지를 다지는 동시에 우리 국민의 안녕을 도모하고자 노력하고 있다. 아직은 $\mathrm{KOICA}$ 를 비롯한 한국 정부가 취약국 지원을 위한 전략 수립 및 운영이 시작 단계라고 할 수 있으나, 지속적으로 분쟁 및 취약국에 대한 지원전략을 국가 차원에서, 범부처 차원에서, 그리고 시행 기간 차원에서 각 층위별로 종합적으로 연계성 있게 개선해나간다면 향후 국제사회의 분쟁 예방 및 평화구축 활동을 보다 주도적으로 운영하는 공여기관으로서 입지를 공고히 하는 동시에 SDGs 달성에 보다 효과적으 로 기여할 수 있을 것으로 기대된다. 


\section{〈참고문헌〉}

권혁주. 2015. 『분쟁 및 취약국 지원 현황 분석: 뉴딜이행 현황을 중심으로』. 성남: 한국국제협력단.

. 2011. “한국 ODA의 분쟁 및 취약국 지원방안." 성남: 한국국제협력단.

Chapman, Nick and Charlotte Vaillant. 2010. "Synthesis of Country Programme Evaluation conducted in Fragile States." London: DFID, available at https:// www.oecd.org/derec/unitedkingdom/45658815.pdf (접속일:2017.06.09.)

DFID. 2015. “Annual Review: Summary Sheet.”London: DFID, available at http://www.google.co.kr/url?sa=t\&rct=j\&q=\&esrc=s\&source=web\&cd=2\& ved=0ahUKEwio5LzY_snUAhWFGpQKHUq9Cf8QFggoMAE\&url=http\%3 A\%2F\%2Fiati.dfid.gov.uk\%2Fiati_documents\%2F4168299.odt\&usg=AFQj CNHA5hNZzjoabqxYtdCRiynlWXypPg (접속일: 2017.06.09.)

. 2012. "Result in Fragile and Conflict-Affected States and Situations."

London: DFID, available at www.gov.uk/government/publications/resultsin-fragile-and-conflict-affected-states-and-situations (접속일: 2017.06.09.)

. 2010a. "UK aid: Changing lives, delivering results." London: DFID. . 2010b. "Building Peaceful States and Societies: practice Paper." London: DFID, available at https://www.gov.uk/government/uploads/system/uploads/ attachment_data/file/67694/Building-peaceful-states-and-societies.pdf (접 속일: 2017.06.09.)

ICAI. 2015. “DFID's Scale-up in Fragile States: Terms of Reference.” London: ICAI, available at http://icai.independent.gov.uk/report/assessing-impactscale-dfids-support-fragile-states/ (접속일: 2016.06.02.)

IDC. 2015. "International Development Committee (IDC) Inquiry: Allocation of Resources" Memorandum by the Department for International Development (DFID). London: IDC.

IDPS. 2011. "New Deal for Engagement in Fragile States.” Paris: IDPS. OECD DAC. 2011. "Evaluating Donor Engagement in Situations of Conflict 
and Fragility." Paris: OECD.

UK Government. 2016. "The 2016 Bilateral and Multilateral Development Review." London: UK Government, available at http://researchbriefings. files.parliament.uk/documents/CBP-7828/CBP-7828.pdf (접속일: 2017.06.02.)

. 2015. "UK aid: tackling global challenges in the national interest." London: UK Government, available at https://www.gov.uk/government/ uploads/system/uploads/attachment_data/file/478834/ODA_strategy_ final_web_0905.pdf (접속일: 2017.06.02)

UK House of Lord. 2016. "Conflict, Stability and Security Fund: Second Report of Session 2016-2017"HLPpaper105, available at https://www.publications. parliament.uk/pa/jt201617/jtselect/jtnatsec/208/208.pdf) (접속일: 2017.06.02.)

USAID. 2005a. "Fragile States Strategy." Washington D.C.: USAID. . 2005b. "Measuring Fragility." Washington D.C.: USAID.

DFID Development Tracker 사이트: devtracker.dfid.gov.uk/ (접속일: 2017.06.08.) OECD 통계사이트: stat.oecd.org (접속일: 2017.06.08.)

$\mathrm{DFID}$ 파키스탄 대상 AAWAZ사업 홈페이지: https://aawaz.org.pk/index.php (접속일: 2017.06.09.) 


\section{〈Annex 1〉 DFID의 취약국 대상 총 지원 규모 및 순위변화(2014-2015)}

\begin{tabular}{|c|c|c|c|c|c|c|c|c|c|}
\hline \multirow{2}{*}{ 번호 } & \multirow{2}{*}{ 국가명 } & \multirow{2}{*}{ 취약성 수준 } & \multicolumn{3}{|c|}{ 지원액 (단위: 백만 달러) } & \multicolumn{4}{|c|}{ 지원액 순위 } \\
\hline & & & 2014 & 2015 & 증감(15/14) & 2014 & 2015 & 증감(15/ & /14) \\
\hline 1 & 에티오피아 & 중간 취약성 & 525.3 & 510.8 & $14.5 \nabla$ & 1 & 2 & & $\nabla$ \\
\hline 2 & 파키스탄 & 높은 취약성 & 395.8 & 537.5 & $141.7 \triangle$ & 2 & 1 & 1 & $\triangle$ \\
\hline 3 & 시에라리온 & 낮은 취약성 & 387.1 & 334.1 & $53.0 \nabla$ & 3 & 4 & 1 & $\nabla$ \\
\hline 4 & 나이지리아 & 중간 취약성 & 372.8 & 387.8 & $15.0 \triangle$ & 4 & 3 & 1 & $\triangle$ \\
\hline 5 & 방글라데시 & 중간 취약성 & 333.7 & 245.2 & $88.4 \nabla$ & 5 & 9 & 4 & $\nabla$ \\
\hline 6 & 아프가니스탄 & 높은 취약성 & 293.7 & 305.0 & $11.4 \triangle$ & 6 & 8 & 2 & $\nabla$ \\
\hline 7 & DR콩고 & 높은 취약성 & 270.2 & 212.9 & $57.3 \nabla$ & 7 & 12 & 5 & $\nabla$ \\
\hline 8 & 남수단 & 높은 취약성 & 267.3 & 313.9 & $46.6 \triangle$ & 8 & 5 & 3 & $\triangle$ \\
\hline 9 & 탄자니아 & $\begin{array}{l}\text { ‘높은 취약성’ } \\
\text { 국가 주변국 }\end{array}$ & 236.3 & 305.2 & $68.8 \triangle$ & 9 & 7 & 2 & $\triangle$ \\
\hline 10 & 중동지역 & 취약 지역 & 244.7 & 25.4 & $219.3 \nabla$ & 10 & 33 & 23 & $\nabla$ \\
\hline 11 & 케냐 & 중간 취약성 & 198.3 & 226.7 & $28.4 \triangle$ & 11 & 11 & 1 & $\nabla$ \\
\hline 12 & 우간다 & 낮은 취약성 & 184.5 & 176.4 & $8.1 \nabla$ & 12 & 13 & 2 & $\nabla$ \\
\hline 13 & 소말리아 & 높은 취약성 & 182.1 & 175.1 & $7.0 \nabla$ & 13 & 14 & 2 & $\nabla$ \\
\hline 14 & 네팔 & 낮은 취약성 & 180.8 & 124.4 & $56.4 \nabla$ & 14 & 20 & 7 & $\nabla$ \\
\hline 15 & 시리아 & 높은 취약성 & 165.9 & 311.2 & $145.3 \triangle$ & 15 & 6 & 8 & $\triangle$ \\
\hline 16 & 사하라이남지역 & 취약지역 & 178.4 & 152.5 & $25.8 \nabla$ & 16 & 16 & & - \\
\hline 17 & 짐바브웨 & 중간 취약성 & 156.9 & 133.2 & $23.7 \nabla$ & 17 & 18 & 3 & $\nabla$ \\
\hline 18 & 잠비아 & $\begin{array}{l}\text { ‘높은 취약성’ } \\
\text { 국가 주변국 }\end{array}$ & 133.3 & 77.8 & $55.4 \nabla$ & 18 & 25 & 9 & $\nabla$ \\
\hline 19 & 예멘 & 높은 취약성 & 128.0 & 119.0 & $9.0 \nabla$ & 19 & 22 & 5 & $\nabla$ \\
\hline 20 & 르완다 & $\begin{array}{l}\text { ‘높은 취약성’ } \\
\text { 국가 주변국 }\end{array}$ & 76.3 & 151.1 & $74.8 \triangle$ & 20 & 17 & 1 & $\triangle$ \\
\hline 21 & 이라크 & 높은 취약성 & 48.5 & 69.1 & $20.6 \triangle$ & 21 & 28 & 9 & $\nabla$ \\
\hline 22 & 레바논 & 중간 취약성 & 30.9 & 130.3 & $99.5 \triangle$ & 22 & 19 & 1 & $\triangle$ \\
\hline 23 & $\begin{array}{c}\text { 중앙아프리카 } \\
\text { 공화국 }\end{array}$ & 높은 취약성 & 26.0 & 27.9 & $1.9 \triangle$ & 23 & 32 & 11 & $\nabla$ \\
\hline 24 & 타지키스탄 & 중간 취약성 & 19.5 & 17.5 & $2.0 \nabla$ & 24 & 34 & 12 & $\nabla$ \\
\hline 25 & 요르단 & $\begin{array}{l}\text { ‘높은 취약성’ } \\
\text { 국가 주변국 }\end{array}$ & 16.6 & 65.9 & $49.3 \triangle$ & 25 & 29 & 6 & $\nabla$ \\
\hline 26 & 카메룬 & 낮은 취약성 & 16.5 & 7.3 & $9.1 \nabla$ & 26 & 41 & 17 & $\nabla$ \\
\hline 27 & 부룬디 & 높은 취약성 & 9.9 & 0 & $9.9 \nabla$ & 27 & - & & - \\
\hline 28 & 라이베리아 & 낮은 취약성 & 9.2 & 15.8 & $6.5 \triangle$ & 28 & 35 & 9 & $\nabla$ \\
\hline 29 & 에리트리아 & 높은 취약성 & 9.2 & 0 & $9.2 \nabla$ & 29 & - & & - \\
\hline 30 & 아이티 & 중간 취약성 & 7.6 & 5.6 & $2.0 \nabla$ & 30 & 43 & 15 & $\nabla$ \\
\hline 31 & 키르기스스탄 & $\begin{array}{l}\text { ‘높은 취약성’ } \\
\text { 국가 주변국 }\end{array}$ & 6.8 & 2.5 & $4.2 \nabla$ & 31 & 46 & 17 & $\nabla$ \\
\hline 32 & 터키 & $\begin{array}{l}\text { ‘높은 취약성’ } \\
\text { 국가 주변국 }\end{array}$ & 6.4 & 2.0 & $4.4 \nabla$ & 32 & 51 & 21 & $\nabla$ \\
\hline 33 & 우크라이나 & 낮은 취약성 & 4.8 & 24.3 & 19.5 & 33 & 34 & 3 & $\nabla$ \\
\hline 34 & 리비아 & 낮은 취약성 & 4.4 & 3.1 & $1.3 \nabla$ & 34 & 45 & 13 & $\nabla$ \\
\hline
\end{tabular}

제 I 장 


\begin{tabular}{|c|c|c|c|c|c|c|c|c|c|}
\hline \multirow{2}{*}{ 번호 } & \multirow{2}{*}{ 국가명 } & \multirow{2}{*}{ 취약성 수준 } & \multicolumn{3}{|c|}{ 지원액 (단위: 백만 달러) } & \multicolumn{4}{|c|}{ 지원액 순위 } \\
\hline & & & 2014 & 2015 & 증감(15/14) & 2014 & 2015 & 증감(15/ & $/ 14)$ \\
\hline 35 & 캄보디아 & 낮은 취약성 & 2.1 & 2.4 & $0.4 \triangle$ & 35 & 47 & 14 & $\nabla$ \\
\hline 36 & 라오스 & $\begin{array}{l}\text { ‘높은 취약성’ } \\
\text { 국가 주변국 }\end{array}$ & 1.3 & 2.3 & $1.1 \triangle$ & 36 & 48 & 14 & $\nabla$ \\
\hline 37 & 튀니지아 & $\begin{array}{l}\text { ‘높은 취약성’ } \\
\text { 국가 주변국 }\end{array}$ & 1.0 & 0.3 & $0.8 \nabla$ & 37 & 56 & 21 & $\nabla$ \\
\hline 38 & 이집트 & 중간 취약성 & 0.9 & 1.1 & $0.2 \triangle$ & 38 & 54 & 18 & $\nabla$ \\
\hline 39 & 모리타니아 & 낮은 취약성 & 0.5 & 0.0 & $0.5 \nabla$ & 39 & - & & - \\
\hline 40 & 말리 & 중간 취약성 & 0.4 & 0.0 & $0.4 \nabla$ & 40 & 55 & 17 & $\nabla$ \\
\hline 41 & 사하라북방지역 & 취약 지역 & 0.0 & 0.0 & - & - & - & & - \\
\hline 42 & 버마 & 높은 취약성 & 0.0 & 0.0 & - & - & - & & - \\
\hline 43 & 차드 & 높은 취약성 & 0.0 & 0.0 & - & - & - & & - \\
\hline 44 & 이란 & 높은 취약성 & 0.0 & 0.0 & - & - & - & & - \\
\hline 45 & 북한 & 높은 취약성 & 0.0 & 0.0 & - & - & - & & - \\
\hline 46 & 앙골라 & 중간 취약성 & 0.0 & 0.0 & - & - & - & & - \\
\hline 47 & 아제르바이잔 & 중간 취약성 & 0.0 & 0.0 & - & - & - & & - \\
\hline 48 & 기니 & 중간 취약성 & 0.0 & 0.0 & - & - & - & & - \\
\hline 49 & 기니비사우 & 중간 취약성 & 0.0 & 0.0 & - & - & - & & - \\
\hline 50 & 키르기스 & 중간 취약성 & 0.0 & 0.0 & - & - & - & & - \\
\hline 51 & $\begin{array}{c}\text { 팔레스타인점령 } \\
\text { 지역(OPT) }\end{array}$ & 중간 취약성 & 0.0 & 0.0 & - & - & - & & - \\
\hline 52 & 투르크메니스탄 & 중간 취약성 & 0.0 & 0.0 & - & - & - & & - \\
\hline 53 & 우즈베키스탄 & 중간 취약성 & 0.0 & 0.0 & - & - & - & & - \\
\hline 54 & 베네수엘라 & 중간 취약성 & 0.0 & 0.0 & - & - & - & & - \\
\hline 55 & 벨라로스 & 낮은 취약성 & 0.0 & 0.0 & - & - & - & & - \\
\hline 56 & 콜롬비아 & 낮은 취약성 & 0.0 & 0.0 & - & - & - & & - \\
\hline 57 & 콩고공화국 & 낮은 취약성 & 0.0 & 0.0 & - & - & - & & - \\
\hline 58 & 코트디부아르 & 낮은 취약성 & 0.0 & 0.0 & - & - & - & & - \\
\hline 59 & 지부티 & 낮은 취약성 & 0.0 & 0.0 & - & - & - & & - \\
\hline 60 & 온두라스 & 낮은 취약성 & 0.0 & 0.0 & - & - & - & & - \\
\hline 61 & 마다가스카르 & 낮은 취약성 & 0.0 & 0.0 & - & - & - & & - \\
\hline 62 & 니제르 & 낮은 취약성 & 0.0 & 0.0 & - & - & - & & - \\
\hline 63 & 파라과이 & 낮은 취약성 & 0.0 & 0.0 & - & - & - & & - \\
\hline 64 & 동티모르 & 낮은 취약성 & 0.0 & 0.0 & - & - & - & & - \\
\hline 65 & 알제리 & $\begin{array}{l}\text { ‘높은 취약성’ } \\
\text { 국가 주변국 }\end{array}$ & 0.0 & 0.0 & - & - & - & & - \\
\hline 66 & 아르메니아 & $\begin{array}{l}\text { ‘높은 취약성’ } \\
\text { 국가 주변국 }\end{array}$ & 0.0 & 0.0 & - & - & - & & - \\
\hline 67 & 태국 & $\begin{array}{l}\text { ‘높은 취약성’ } \\
\text { 국가 주변국 }\end{array}$ & 0.0 & 0.0 & - & - & - & & - \\
\hline
\end{tabular}

출처: OECD 통계사이트(stat.oecd.org) 내용 바탕으로 저자 재구성 (접속일: 2017.06.08.) 


\section{〈Annex 2〉 DFID의 취약국 대상 프로젝트 예산 규모 및 순위(FY16/17-FY17/18)}

\begin{tabular}{|c|c|c|c|c|c|c|}
\hline \multirow[t]{2}{*}{ 번호 } & \multirow[t]{2}{*}{ 국가명 } & \multirow[t]{2}{*}{ 취약성 수준 } & \multicolumn{2}{|c|}{$\begin{array}{l}\text { 총 프로젝트 예산액 } \\
\text { (단위: 백만 달러) }\end{array}$} & \multicolumn{2}{|c|}{ 총 프로젝트 예산순위 } \\
\hline & & & FY16/17 & $\mathrm{FY} 17 / 18$ & FY16/17 & FY17/18 \\
\hline 1 & 파키스탄 & 높은 취약성 & 549.2 & 396.1 & 1 & 1 \\
\hline 2 & 에티오피아 & 중간 취약성 & 420.6 & 277.7 & 2 & 3 \\
\hline 3 & 나이지리아 & 중간 취약성 & 388.7 & 285.8 & 3 & 2 \\
\hline 4 & 시리아 & 높은 취약성 & 281.9 & 170.4 & 4 & 9 \\
\hline 5 & 시에라리온 & 낮은 취약성 & 267.4 & 141.7 & 5 & 13 \\
\hline 6 & 탄자니아 & $\begin{array}{l}\text { ‘높은 취ㅇㅑㅑ성' } \\
\text { 국가 주변국 }\end{array}$ & 247.3 & 237.3 & 6 & 4 \\
\hline 7 & 요르단 & $\begin{array}{l}\text { ‘높은 취ㅇㅑㅑ성' } \\
\text { 국가 주변국 }\end{array}$ & 234.7 & 63.8 & 7 & 20 \\
\hline 8 & 남수단 & 높은 취약성 & 222.1 & 194.2 & 8 & 5 \\
\hline 9 & 아프가니스탄 & 높은 취약성 & 215.6 & 162.4 & 9 & 10 \\
\hline 10 & 소말리아 & 높은 취약성 & 215.2 & 190.1 & 10 & 6 \\
\hline 11 & 방글라데시 & 중간 취약성 & 210.2 & 158.9 & 11 & 11 \\
\hline 12 & 사하라이남지역 & 취약 지역 & 205.3 & 84.3 & 12 & 15 \\
\hline 13 & DR콩고 & 높은 취약성 & 193.9 & 170.7 & 13 & 8 \\
\hline 14 & 케냐 & 중간 취약성 & 184.0 & 171.5 & 14 & 7 \\
\hline 15 & 레바논 & 중간 취약성 & 150.9 & 73.0 & 15 & 17 \\
\hline 16 & 네팔 & 낮은 취약성 & 134.2 & 105.8 & 16 & 14 \\
\hline 17 & 짐바브웨 & 중간 취약성 & 120.5 & 58.8 & 17 & 22 \\
\hline 18 & 우간다 & 낮은 취약성 & 120.1 & 44.9 & 18 & 25 \\
\hline 19 & 이라크 & 높은 취약성 & 120.0 & 50.3 & 19 & 24 \\
\hline 20 & 버마 & 높은 취약성 & 114.2 & 72.8 & 20 & 18 \\
\hline 21 & 터키 & $\begin{array}{l}\text { ‘높은 취약성' } \\
\text { 국가 주변국 }\end{array}$ & 110.4 & 157.5 & 21 & 12 \\
\hline 22 & $\begin{array}{c}\text { 팔레스타인점령지역 } \\
\text { (OPT) }\end{array}$ & 중간 취약성 & 86.0 & 77.9 & 22 & 16 \\
\hline 23 & 예멘 & 높은 취약성 & 82.7 & 62.9 & 23 & 21 \\
\hline 24 & 르완다 & $\begin{array}{l}\text { ‘높은 취약성' } \\
\text { 국가 주변국 }\end{array}$ & 76.0 & 55.3 & 24 & 23 \\
\hline 25 & 잠비아 & $\begin{array}{l}\text { '높은 취약성' } \\
\text { 국가 주변국 }\end{array}$ & 64.8 & 70.7 & 25 & 19 \\
\hline 26 & 중동지역 & 취약 지역 & 24.5 & 9.3 & 26 & 27 \\
\hline 27 & 중앙아프리카공화국 & 높은 취약성 & 21.4 & 14.0 & 27 & 26 \\
\hline 28 & 우크라이나 & 낮은 취약성 & 16.7 & 2.5 & 28 & 31 \\
\hline 29 & 타지키스탄 & 중간 취약성 & 6.8 & 7.3 & 29 & 28 \\
\hline 30 & 라이베리아 & 낮은 취약성 & 5.9 & 4.2 & 30 & 30 \\
\hline 31 & 부룬디 & 높은 취약성 & 5.8 & 0.5 & 31 & 35 \\
\hline 32 & 리비아 & 높은 취약성 & 4.8 & 0.8 & 32 & 32 \\
\hline 33 & 키르기스스탄 & $\begin{array}{l}\text { ‘높은 취약성' } \\
\text { 국가 주변국 }\end{array}$ & 4.0 & 5.8 & 33 & 29 \\
\hline 34 & 아이티 & 중간 취약성 & 3.8 & 0.1 & 34 & 36 \\
\hline 35 & 캄보디아 & 낮은 취약성 & 2.4 & 0.5 & 35 & 34 \\
\hline 36 & 말리 & 중간 취약성 & 0.4 & 0.6 & 36 & 33 \\
\hline
\end{tabular}

제I장 


\begin{tabular}{|c|c|c|c|c|c|c|}
\hline \multirow[t]{2}{*}{ 번호 } & \multirow[t]{2}{*}{ 국가명 } & \multirow[t]{2}{*}{ 취약성 수준 } & \multicolumn{2}{|c|}{$\begin{array}{l}\text { 총 프로젝트 예산액 } \\
\text { (단위: 백만 달러) }\end{array}$} & \multicolumn{2}{|c|}{ 총 프로젝트 예산순위 } \\
\hline & & & FY16/17 & FY17/18 & FY16/17 & FY17/18 \\
\hline 37 & 사하라이북지역 & 취약 지역 & 0 & 0.0 & - & - \\
\hline 38 & 니제르 & 낮은 취약성 & 0 & 0.0 & - & - \\
\hline 39 & 카메룬 & 낮은 취약성 & 0 & 0.0 & - & - \\
\hline 40 & 에리트리아 & 높은 취약성 & 0 & 0.0 & - & - \\
\hline 41 & 라오스 & $\begin{array}{l}\text { ‘높은 취약성’ } \\
\text { 국가 주변국 }\end{array}$ & 0 & 0.0 & - & - \\
\hline 42 & 튀니지아 & $\begin{array}{l}\text { ‘높은 취약성’ } \\
\text { 국가 주변국 }\end{array}$ & 0 & 0.0 & - & - \\
\hline 43 & 이집트 & 중간 취약성 & 0 & 0.0 & - & - \\
\hline 44 & 모리타니 & 낮은 취약성 & 0 & 0.0 & - & - \\
\hline 45 & 차드 & 높은 취약성 & 0 & 0.0 & - & - \\
\hline 46 & 이란 & 높은 취약성 & 0 & 0.0 & - & - \\
\hline 47 & 북한 & 높은 취약성 & 0 & 0.0 & - & - \\
\hline 48 & 앙골라 & 중간 취약성 & 0 & 0.0 & - & - \\
\hline 49 & 아제르바이잔 & 중간 취약성 & 0 & 0.0 & - & - \\
\hline 50 & 기니 & 중간 취약성 & 0 & 0.0 & - & - \\
\hline 51 & 기니바소 & 중간 취약성 & 0 & 0.0 & - & - \\
\hline 52 & 키르기스스탄 & 중간 취약성 & 0 & 0.0 & - & - \\
\hline 53 & 투르크메니스탄 & 중간 취약성 & 0 & 0.0 & - & - \\
\hline 54 & 우즈베키스탄 & 중간 취약성 & 0 & 0.0 & - & - \\
\hline 55 & 베네수엘라 & 중간 취약성 & 0 & 0.0 & - & - \\
\hline 56 & 벨라루스 & 낮은 취약성 & 0 & 0.0 & - & - \\
\hline 57 & 콜롬비아 & 낮은 취약성 & 0 & 0.0 & - & - \\
\hline 58 & 콩고 & 낮은 취약성 & 0 & 0.0 & - & - \\
\hline 59 & 코트디부아르 & 낮은 취약성 & 0 & 0.0 & - & - \\
\hline 60 & 지부디 & 낮은 취약성 & 0 & 0.0 & - & - \\
\hline 61 & 온두라스 & 낮은 취약성 & 0 & 0.0 & - & - \\
\hline 62 & 마다가스카르 & 낮은 취약성 & 0 & 0.0 & - & - \\
\hline 63 & 파라과이 & 낮은 취약성 & 0 & 0.0 & - & - \\
\hline 64 & 동티모르 & 낮은 취약성 & 0 & 0.0 & - & - \\
\hline 65 & 알제리 & $\begin{array}{l}\text { ‘높은 취약성' } \\
\text { 국가 주변국 }\end{array}$ & 0 & 0.0 & - & - \\
\hline 66 & 아르메니아 & $\begin{array}{l}\text { ‘높은 취약성’ } \\
\text { 국가 주변국 }\end{array}$ & 0 & 0.0 & - & - \\
\hline 67 & 태국 & $\begin{array}{l}\text { ‘높은 취약성' } \\
\text { 국가 주변국 }\end{array}$ & 0 & 0.0 & - & - \\
\hline \multicolumn{3}{|c|}{ 취약국/지역 대상 프로젝트 예산 총합(A) } & 5112.6 & $3,580.5$ & & \\
\hline \multicolumn{3}{|c|}{$\mathrm{DFID}$ 전체 프로젝트 예산 총합(B) } & 12632.4 & $8,041.4$ & & \\
\hline \multicolumn{3}{|c|}{$\begin{array}{c}\text { 전체 프로젝트 예산 대비 취약국/ } \\
\text { 지역 예산 비중(A/B) }\end{array}$} & $40.5 \%$ & $44.5 \%$ & & \\
\hline
\end{tabular}

* 상기 표는 2017년도 평균 환율 적용 $(£ 1=\$ 1.26)$

출처: DFID Development Tracker 사이트(devtracker.dfid.gov.uk/) 내용 바탕으로 저자 재구성 (접속일: 2017.06.08.) 


\section{〈Annex 3〉 DFID 파키스탄 지원사례: AAWAZ 사업7)}

\section{$\square$ 사업 개요}

DFID의 AAWAZ 프로그램은 3,450만 파운드의 예산이 투입되어 2012년부터 2017년까지 5년간 진행됨

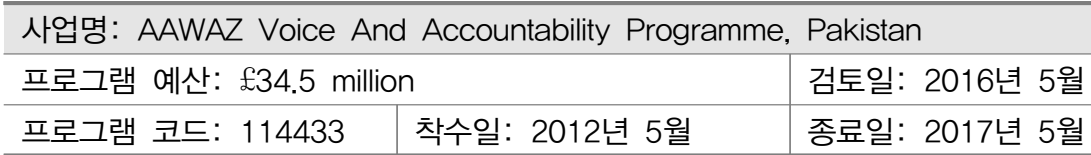

\section{$\square$ 사업 배경}

○ 파키스탄은 높은 수준의 폭력, 불안정, 빈곤, 불평등을 보이며, 인권과 종교적 관용이 점차 악화 되고 있음. 특히 파키스탄의 여성은 교육수준이 낮고 폭력과 극심한 불평등을 겪고 있으며, 종교집단과 소수민족 또한 불안정한 상황에 처해 있음. 더불어 여성, 어린이, 소수민족의 권리 를 보호하기 위해 마련된 법률과 정책의 집행수준이 낮음

$\circ$ AAWAZ 프로그램은 정보제공과 시민참여 활동을 통해 여성들에게 정치적 권한을 부여하고 지역사회의 갈등을 해소하며, 보건 · 교육 분야의 공공서비스를 개선하여 국가의 시민권리 실 현을 촉진하기 위해 착수됨

$\circ$ 동 프로그램을 통해 공동의 기반과 상호 이해를 구축하고 긍정적인 변화를 지원하기 위해 연대 와 네트워크를 형성하는 사회자본 구축을 기대함

\section{주요 분야 및 지역}

○AWAZ 프로그램은 여성과 소외계층을 포함한 파키스탄 시민들이 보다 개방적이고 포괄적이 며 책임 있는 민주적 절차를 이용할 수 있도록 보장하고자 함

$\circ$ 여성과 소수민족의 권리, 정치참여와 의사결정, 관용과 폭력예방, 서비스 개선을 요구하는 시민 들의 민원에 대한 책무성 강화에 중점을 둠

7) 동 사례의 내용 정리는 다음의 두 자료를 바탕으로 정리되었다: “AAWAZ 사업 소개 홈페이지” (https://aawaz.org. pk/index.php, 접속일: 2017.06.09.) 와 DFID. 2015. “Annual Review: Sumamry Sheet," available at http://www.google.co.kr/url?sa=t\&rct=j\&q=\&esrc=s\&source=web\&cd=2\&ved=0ahUKEwio5LzY_ snUAhWFGpQKHUq9Cf8QFggoMAE\&url=http\%3A\%2F\%2Fiati.dfid.gov.uk\%2Fiati_documents\%2F41 68299.odt\&usg=AFQjCNHA5hNZzjoabqxYtdCRiynlWXypPg（접속일: 2017.06.09.） 
$\circ$ 사업지역은 펀잡주(Punjab)와 카이버파 크툰크와주(KPK)에 위치한 45개 지역의 4,500 개 마을에서 시행됨

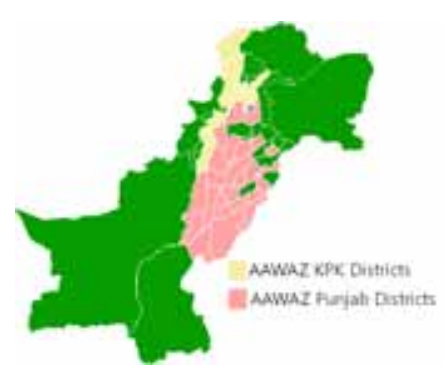

〈그림 1〉AAWAZ 사업지역

\section{ㅁ 주요 접근방식}

○ AAWAZ 프로그램은 변화이론을 적용하여 여성, 남성, 사회적 소외계층을 포함한 파키스탄 시민들의 인식변화를 유도함. 프로그램 전반과 각 프로그램 산출물(output)의 두 가지 측면에 서 변화이론을 제시함

- 젠더 포용성 향상을 통해 정치에 참여하는 사회적 행위자들의 범위 확대

- 지역사회의 화합과 관용을 통한 보다 조직화된 이슈 기반의 정치

- 정치적 책무성 향상

- 증거와 연구를 통한 이슈 기반의 정치 도모

\section{$\square$ 파트너}

재재정지원: 영국 국제개발부(Department for International Development, DFID)

$\circ$ 프로그램 시행의 관리조직: Development Alternatives Inc. (DAl)

○ 파키스탄의 주요 시민사회 단체인 Aurat Foundation (AF), South-Asia Partnership Pakistan (SAP-PK), Strengthening Participatory Organisation (SPO), Sungi Development Foundation (SF)가 컨소시엄을 형성하여 지역사회와 직접적으로 협력 
ㅁ 주요 성과: 지표의 $90 \%$ 충족

\begin{tabular}{c|l}
\hline Impact & 파키스탄에 안전하고, 포괄적인, 관용적인 민주주의 확립 \\
\hline Outcome & 시민들에게 보다 개방적이고 포괄적이며 책임 있는 민주적 절차 보장 \\
\hline \multirow{5}{*}{ Outputs } & $\begin{array}{l}\text { (1) 여성이 연방 · 주 · 지방 차원에서 정치와 공공 부문에 보다 안전화과게 참옹뎡체의 평화로운 분쟁해결, 공동의 해결책을 위한 노력 } \\
\text { (3) 여성과 소외집단들의 서비스 향상에 대한 민원 개선 } \\
\text { (4) 수집 · 정리된/정치지도자와 엘리트의 지지를 받는 증거개선 }\end{array}$ \\
\hline
\end{tabular}

- 5,125개의 AAWAZ 단체/네트워크에 176,955 명의 회원(90,430명의 여성, 86,408 명의

남성, 117 명의 트랜스젠더)이 활동 중임

○ 300 만 명, 6 백만 명이 넘는 가난한 사람들에게 직 · 간접적으로 영향을 미침

○ 여성 1,342명(KP 370명, 펀잡 972명)이 지방선거 후보자로 출마하고 약 280명이 선출됨

매 분기마다 74,000명이 넘는 여성들이 AAWAZ Aagahi Centers(시민 상담소)에 연락하여 공공서비스에 대한 지원과 조언 · 정보를 얻음

$\circ$ 시민 타운홀미팅(khuli kachehries)과 주정부 관계자와 일대일 세션(보건, 교육, 물 · 위생 서비스 개선 요구)을 통해 300 만 명 이상의 사람들에게 혜택을 제공함

$\circ$ 모든 4,500개의 마을에 갈등을 예방하는 조기대응메커니즘 구축

$\circ$ 증오성 발언과 여성폭력 근절, 지방정부 개선을 위한 캠페인을 통해 265 만 명의 사람들에게 영향을 미침

$\circ$ AAWAZ 파트너의 활동으로 펀잡의 가정폭력방지법(Domestic Violence Act, 2016) 통과함

○ AAWAZ 프로그램의 전반적인 점수는 2013년 B에서 2016년 A+로 향상되었으며, 위험 정 도는 2014년을 제외하고 중간 수준을 보임 
세부 산출물 점수 기준 및 항목별 점수 결과

\begin{tabular}{c|c|c|c|c}
\hline 년도 & 2013 & 2014 & 2015 & 2016 \\
\hline 프로그램 점수 & $\mathrm{B}$ & $\mathrm{A}$ & $\mathrm{A}$ & $\mathrm{A}+$ \\
\hline 위험 수준 & 중간 & 낮음 & 중간 & 중간 \\
\hline
\end{tabular}

안출물1: 펀잡과 KPK 지역의 여성이 연방 · 주 · 지방 치원에서 정치와 공공 부문에 보다 안전 하게 참여

\begin{tabular}{c|c|c|c}
\hline 산출물 번호 & 1 & 산출물 점수 & $A+$ \\
\hline 위험 & 중간 & 영향력 비중(\%) & $30 \%$ \\
\hline $\begin{array}{c}\text { 지난 연간검토 이후 } \\
\text { 위험 수준이 변경되었는가? }\end{array}$ & 아니오 & $\begin{array}{c}\text { 지난 연간검토 이후 영향력 비중(\%)이 } \\
\text { 변경되었는가? }\end{array}$ & 아니오 \\
\hline
\end{tabular}

산출물2: 펀잡과 KPK 지역에서 시민과 공동체가 분쟁을 평화롭게 해결하고 공동의 해결책을 위해 함께 노력

\begin{tabular}{c|c|c|c}
\hline 산출물 번호 & 2 & 산출물 점수 & A+ \\
\hline 위험 & 중간 & 영향력 비중(\%) & $20 \%$ \\
\hline $\begin{array}{c}\text { 지난 연간검토 이후 } \\
\text { 위험 수준이 변경되었는가? }\end{array}$ & 아니오 & $\begin{array}{c}\text { 지난 연간검토 이후 영향력 비중(\%)이 } \\
\text { 변경되었는가? }\end{array}$ & 아니오 \\
\hline
\end{tabular}

○ 산출물3: 펀잡과 KPK 지역에서 여성과 소외집단들의 서비스 향상에 대한 민원 개선

\begin{tabular}{c|c|c|c}
\hline 산출물 번호 & 3 & 산출물 점수 & $A+$ \\
\hline 위험 & 중간 & 영향력 비중(\%) & $30 \%$ \\
\hline $\begin{array}{c}\text { 지난 연간검토 이후 } \\
\text { 위험 수준이 변경되었는가? }\end{array}$ & 아니오 & $\begin{array}{c}\text { 지난 연간검토 이후 영향력 } \\
\text { 비중(\%)이 변경되었는가? }\end{array}$ & 아니오 \\
\hline
\end{tabular}

안출물4: 펀잡과 KPK 지역에서 수집 - 종합되고 정치지도자와 엘리트의 지지를 받는 증거 개선

\begin{tabular}{c|c|c|c}
\hline 산출물 번호 & 4 & 산출물 점수 & $A+$ \\
\hline 위험 & 낮음 & 영향력 비중(\%) & $20 \%$ \\
\hline $\begin{array}{c}\text { 지난 연간검토 이후 } \\
\text { 위험 수준이 변경되었는가? }\end{array}$ & 아니오 & $\begin{array}{c}\text { 지난 연간검토 이후 영향력 비중(\%)이 } \\
\text { 변경되었는가? }\end{array}$ & 아니오 \\
\hline
\end{tabular}




\section{미사점}

$\circ$ 시민참여를 강화하는 것이 필요함

신뢰를 구축하고 여성 · 취약계층 · 빈민들이 소외되지 않도록 지방정부와 AAWAZ 지역사회 간 관계강화

교훈을 확산하고 혁신적인 방법을 개발하고 지속가능성을 높이기 위해 여성의 역량 강화를 통해 450개의 Aagahi 센터 지원

○ 기존의 성취를 강화하고, 여성, 소수자, 청년들의 참여와 리더십을 발전시키는 것이 필요함.

또한 교훈을 체계적으로 공유하고 적용하는 것이 중요함

시행 파트너들의 혁신적인 개선과 모든 지역에 동일한 수준의 프로그램의 질 보장

보건과 교육 등의 타 DFID 프로그램에 혜택 극대화

○ 종합 프로그램과 재정관리 정보를 이용하여 전략 방향을 설정하고 감독하기 위해 운영위원회 (ASC) 권한 부여가 필요함

$\circ$ 금액에 합당한 가치(Value for money) 및 재정규정 준수를 지속적으로 강화하는 것이 중요함 프로그램에 직접적인 영향을 미치는 수혜자에 대해 집계되지 않은 데이터/정보수집 강화 재정 시스텀을 강화하고 프로그램의 위험을 중간에서 낮은 수준으로 전환할 수 있도록 회계감 사 권고사항 이행

○ DFID의 지원 유지

AAWAZ는 지속가능성을 높이기 위해 기간과 일정 비용을 확대하고, 새로운 프로그램을 위한 영역을 확인해야함 


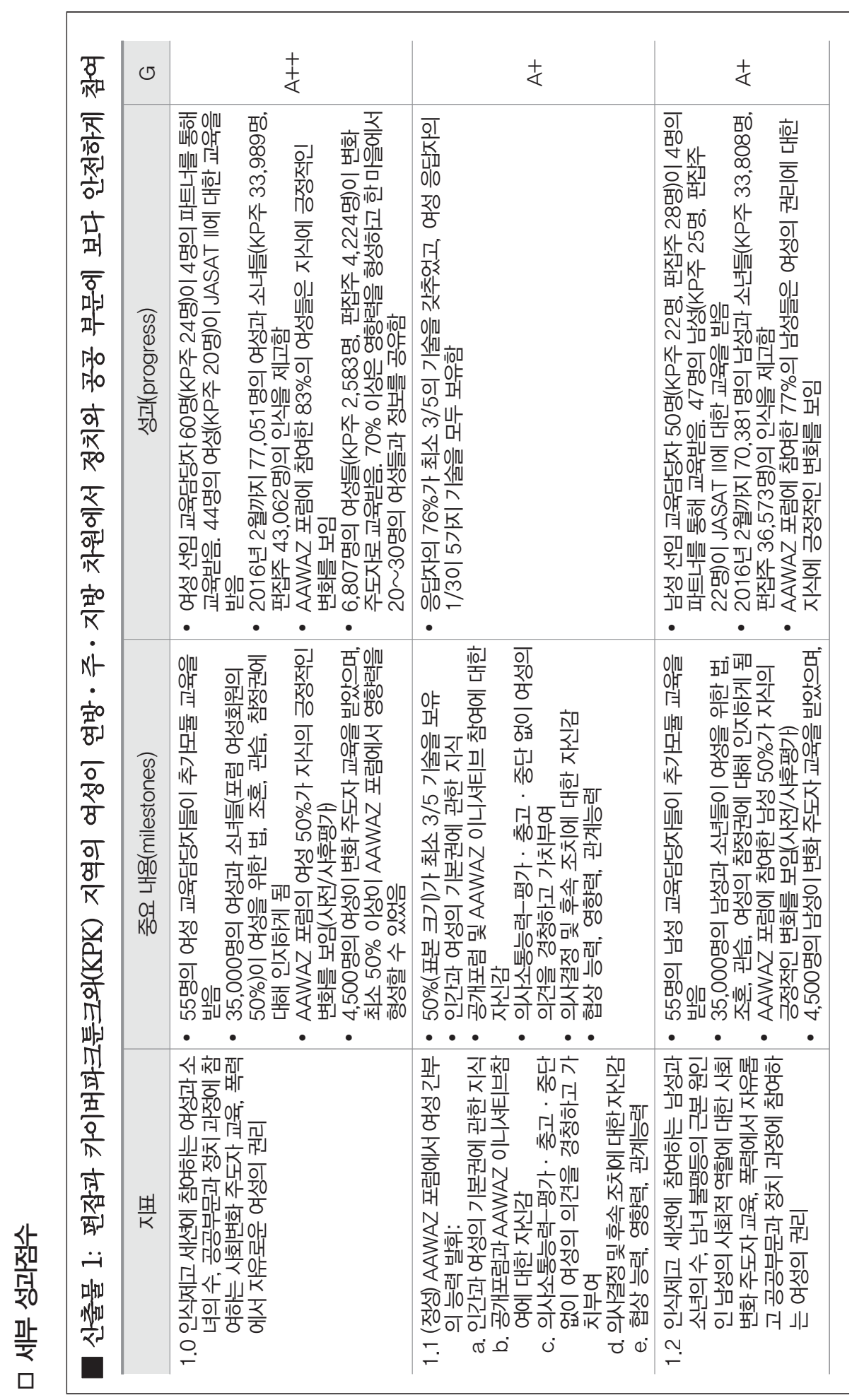




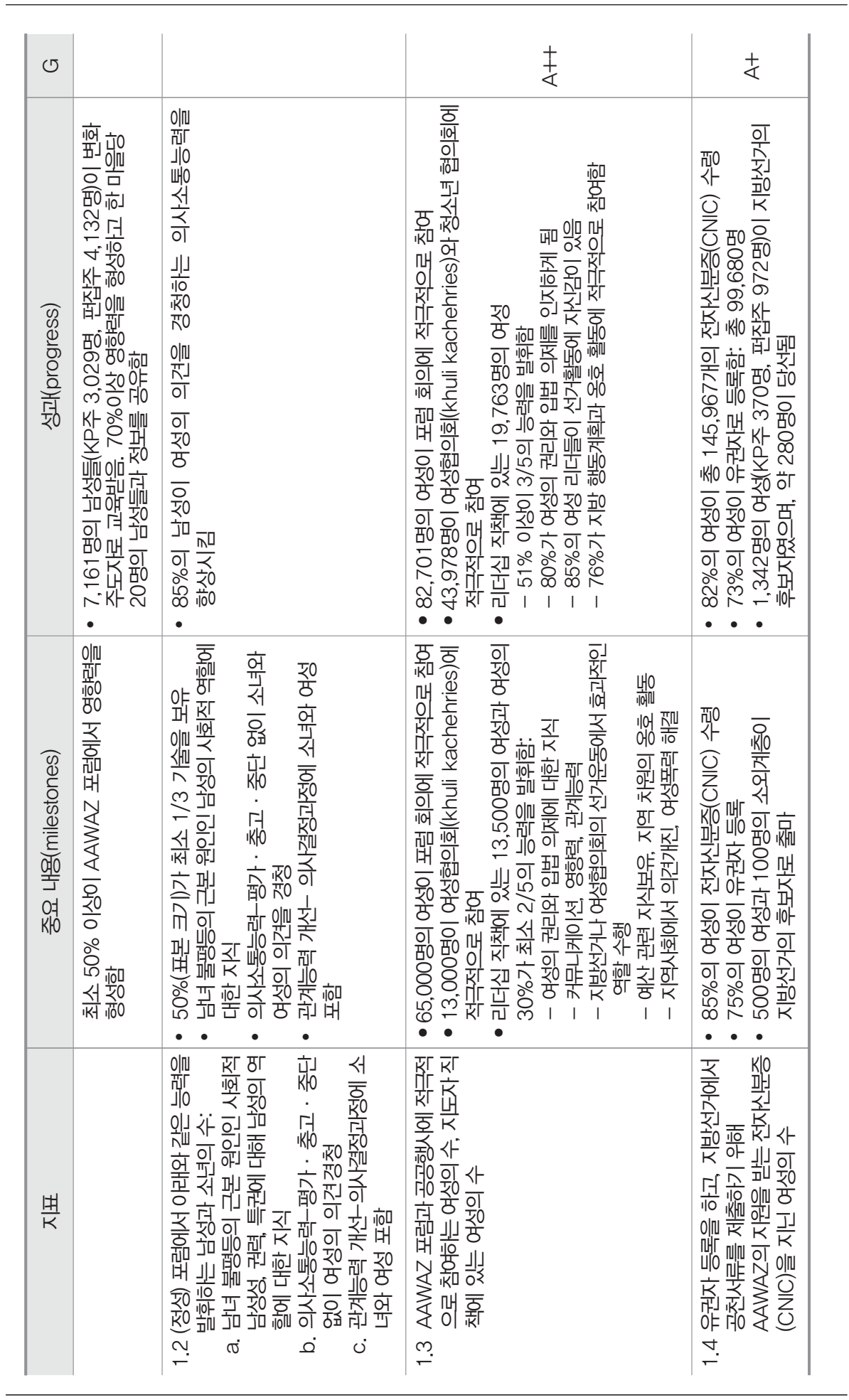

제I 장

개

발

협

력

이

슈

제II장

제피장 


\begin{tabular}{|c|c|c|c|c|c|}
\hline$\frac{\sqrt{10}}{\text { of }}$ & $\circlearrowleft$ & 去 & $\varangle$ & $\underset{<}{ \pm}$ & $\underset{4}{f}$ \\
\hline 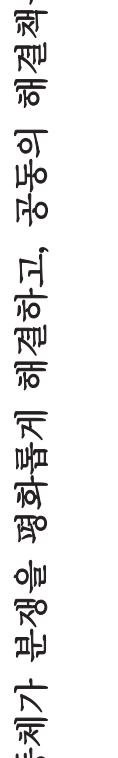 & 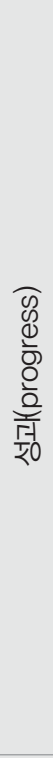 & 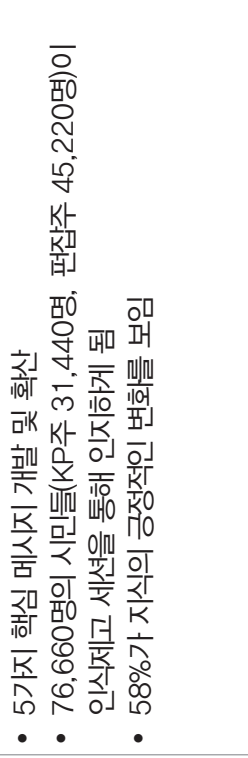 & 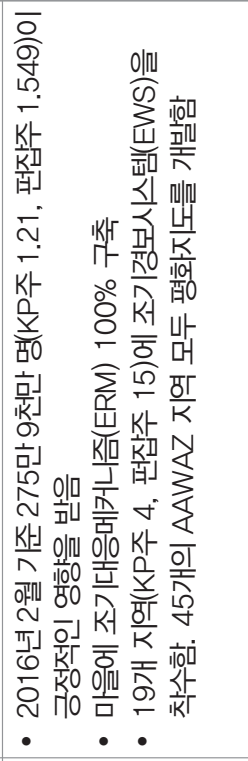 & 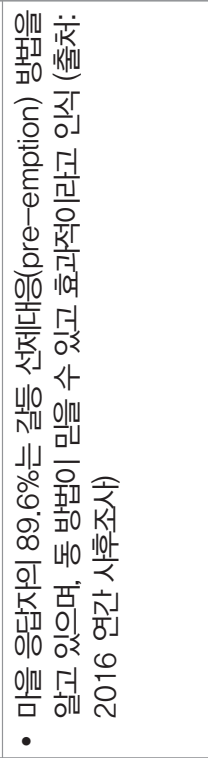 & 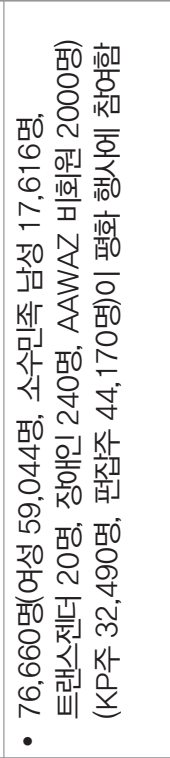 \\
\hline 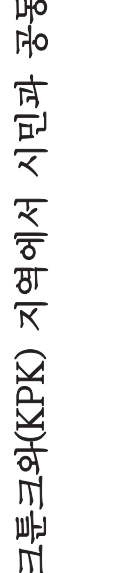 & 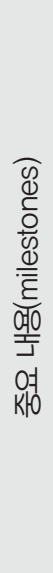 & 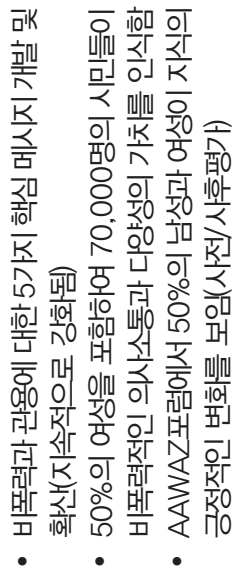 & 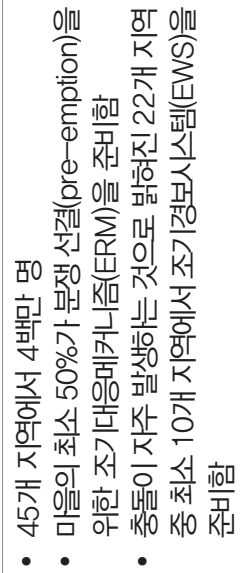 & 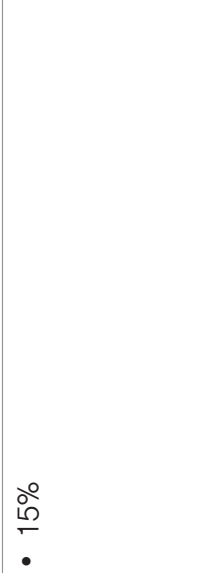 & 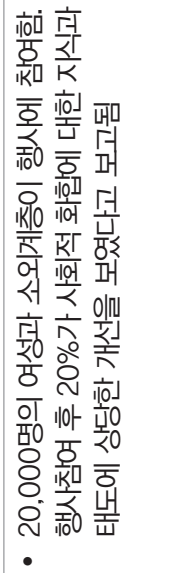 \\
\hline  & $\frac{\text { 击 }}{\mathrm{K}}$ & 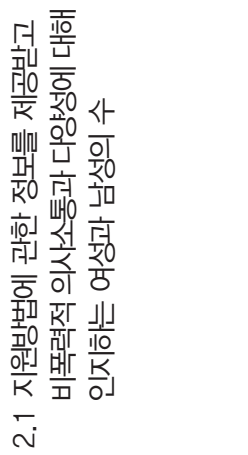 &  & 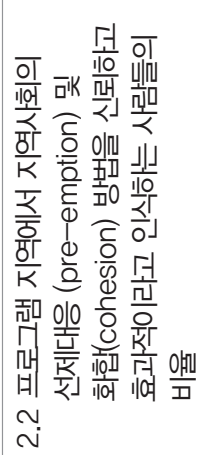 & 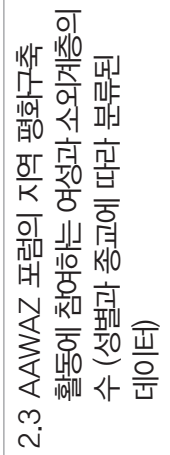 \\
\hline
\end{tabular}




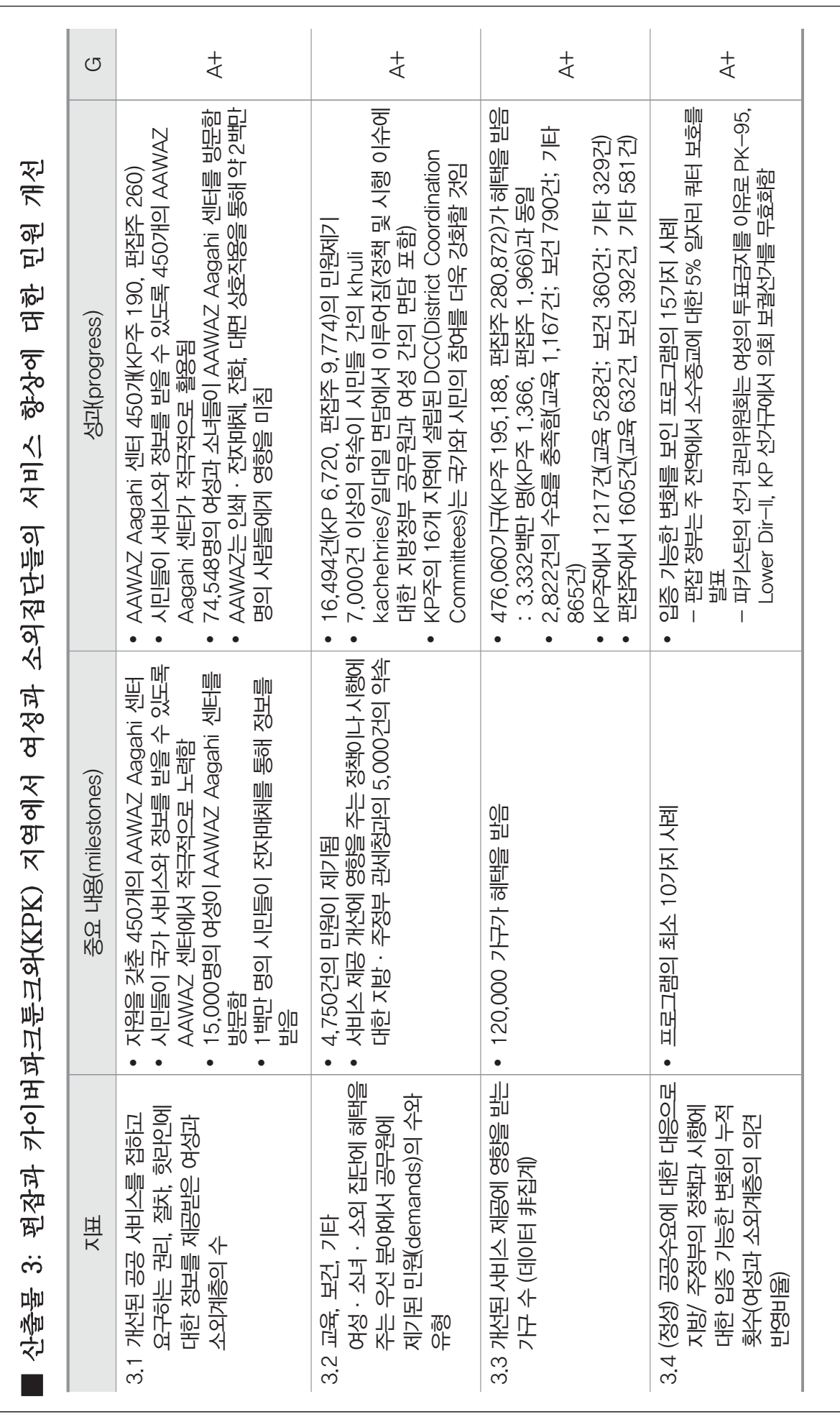

제I 장

개

발

협

력

이

슈

제II 장

제표장 


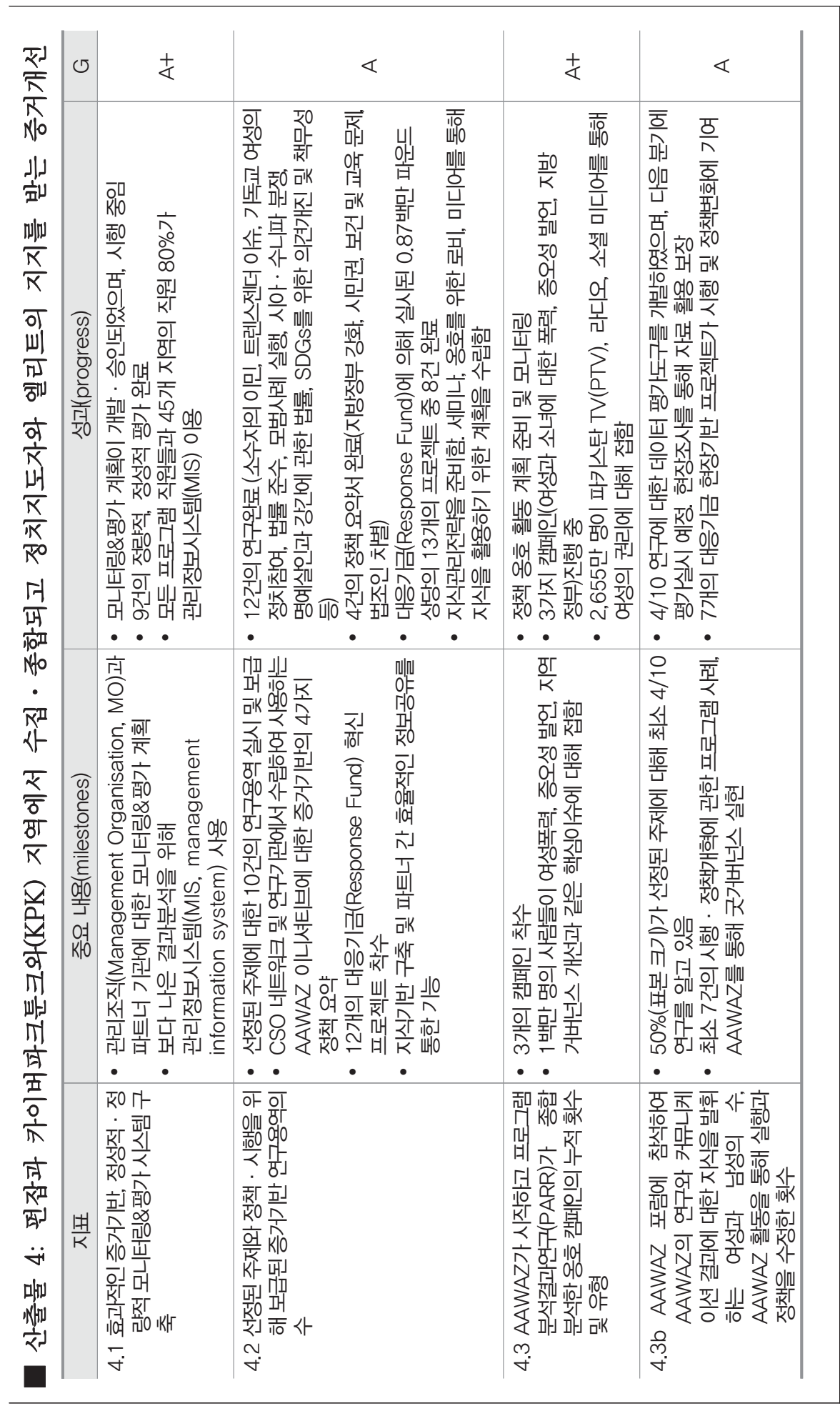

